\title{
Osmanlı Sarayının İki Aylık Meyve ve Çiçek Masrafı Fruit and Flower Expenditures of the Ottoman Palace for a Period of Two Months
}

\section{İzzet SAK ${ }^{*}$}

$\ddot{O}_{z}$

16. yüzyıl ile 19. yüzyıl arasında Osmanlt sarayında tüketilen yiyecekler arasında çeşitli meyvelerin yanında çiçekler de bulunuyordu. Bu ürünler İstanbul ve çevresinden temin edildiği gibi padişaha âit hassa bahçelerde de yetiştiriliyordu. Bu çalışmada 18. yüzyllın ortalarında iki ayrn aya âit, Osmanlt sarayının meyve ve çiçek masraflarını içeren iki liste verilmiştir. Listelerde ay içerisinde günlük olarak saraya alınan meyve ve çiçek masraflart ile bazı özel günlerde ve bayramlarda padişah, dârüssaâde ă̆ast, padişah kadınlart ve saraydaki diğer ileri gelen görevlilere alınan meyve ve çiçek masrafları kaydedilmiştir.

Anahtar Kelimeler: Saray, Osmanle Saray, Saray Masrafi, Meyve, Osmanli'da Meyve, Çiçek, Osmanll'da Çiçek.

\section{Abstract}

At the Ottoman Palace between $16^{\text {th }}$ and the $19^{\text {th }}$ centuries, flowers were consumption in use besides different fruits. These products were achieved from Istanbul and its vicinity and also these were raised at the special gardens of the Sultan. This article presents, two lists belonging to two different months in the mid $18^{\text {th }}$ century. The lists contain the fruit and flower expenditure of the Ottoman Palace. The lists show the monthly expenses of daily-purchased fruit and flower to the palace and they also registered the expenditure of the products purchased for some special days and holidays bought to the Sultan, the dârüssaâde ağast, the women of the Sultan and to the other important officials in the Palace.

Key Words: Palace, the Ottoman Palace, Palace Expenditure, Fruit, Fruit at the Ottoman, Flower, Flower at the Ottoman.

\footnotetext{
*Yard. Doç. Dr., Selçuk Üniversitesi, Fen-Edebiyat Fakültesi, Tarih Bölümü.
} 


\section{Giriş}

Dört yüzyıla yakın bir süre Osmanlı Devleti'nin yönetim merkezi olan ve içinde padişah, hânedân üyeleri, üst düzey devlet görevlileri, pek çoğu ileride devletin yönetim kadrolarında görev alacak Enderûn mensupları, bazıları ileride padişahın haremine girecek olan câriyeler, hadım ağaları ve çok sayıda görevlinin yaşadığ1 Topkapı Sarayı'nın i‘âşesinin nasıl karşılandığı, tüketilen gida maddeleri ve yenilen yemekler her zaman merak konusu olmuştur. Bu merakı gidermek için son zamanlarda, Osmanlı toplumunun yeme-içme alışkanlıkları ve saray mutfağının masrafları hakkında yapılan araştırmalar bir hayli artmıştır. Bu konuda pek çok araştırma yapıldığı gibi sarayın masraf defterlerinin yayınlandığı bazı belge neşirleri de gerçekleştirilmiştir. Biz de bu çalışmada, Osmanlı sarayının 18. yüzyıl ortalarında iki aylık meyve ve çiçek masrafını ele alarak inceleyeceğiz. I. Mahmûd döneminde, birincisi 1-30 Muharrem 1154/19 Mart-17 Nisan 1741 ve ikincisi de 1-30 Ramazân 1158 / 27 Eylül-16 Ekim 1745 tarihlerine âit meyve ve çiçek masraflarını gösteren iki ayrı liste bu çalışmanın konusunu teşkil edecektir. Çalışmanın sonunda da, değerlendirmeleri yapılan listelerin metinleri verilecektir. Ancak listelerin verdiği bilgileri değerlendirmeye geçmeden önce, Osmanlı sarayının meyve ve çiçek ihtiyacı ile bunların nerelerden ve nasıl karşılandığı hakkında kısaca bilgi vermenin faydalı olacağı kanaatindeyiz.

\section{Osmanlı Sarayında Tüketilen Meyveler}

16. yüzyıl ile 19. yüzyıl arasında çok fazla bir değişiklik göstermeyen Osmanlı Devleti'ndeki meyve türleri hem halkın hem de sarayın beslenme alışkanlıklarına yön vermiştir. Osmanlı sarayında tüketilen meyvelerin isimlerini tespit edebilmek için dönem içinde düzenlenen saray mutfağ 1 'âşe defterlerine bakmak kâfidir. Bu amaçla burada, daha önce yayınlanmış olan i'âşe defterlerinden faydalanılacaktır.

17. ve 18. yüzyıllarda da pek fazla bir değişiklik göstermeyen Osmanlı sarayına giren meyvelerin tespiti için, 16. yüzyıla âit olmasına rağmen,' Ö. Lütfi Barkan tarafından yayınlanmış olan-saray mutfağı masraf defterlerinden büyük ölçüde istifâde edilecektir ${ }^{1}$.

Buna göre, 1 Muharrem-12 Ramazân 962 (26 Kasım 1554-31 Temmuz 1555) tarihleri arasına âit 8 ay 12 günlük dönem içerisinde Sarây-1 Âmire mutfağına mevîz-i sürh (kırmızı üzüm), mevîz-i siyah (siyah üzüm), mevîz-i mürg (kuş üzümü), kayısı, incir, bâdem, âlû (erik), zerd-âlû, tüffâh (elma), hayva, turunç, nâr-dâne, kesdâne, nârdeng-i Gelibolu, kiras, vişne, emrûd-1 tâze ve kızılcık gibi meyveler satın alınmışıı².

\footnotetext{
'Ömer Lütfi Barkan, "İstanbul Sarayına Ait Muhasebe Defterleri", Belgeler, C.IX, S.13, Ankara 1979, s.1-380.

29.000 kıyye mevîz-i sürh, 10.491 kıyye mevîz-i siyah, 159,5 kıyye mevîz-i mürg, 197,5 kıyye kayısı, 804 kıyye incir, 1.701 kıyye 100 dirhem bâdem, 869,5 kıyye âlû, 777,5 kıyye zerd-âlû, 477 kıyye tüffâh, 90 kıyye hayva, 410 aded turunç, 1.171 kıyye 150 dirhem nâr-
} 
1 Muharrem ile 29 Zilhicce 963 tarihleri arasında ise Eski Saray'da bulunan Vâlide Sultan dâiresi için alınan yiyecekler arasında badem, mevîz-i sürh, mevîz-i siyah, incir-i lob, kayısı, âlû-i siyah (siyah erik), zerd-âlû, nârdenk gibi meyveler yer almıştır ${ }^{3}$. Aynı dönemde cevâri-i hassa için alınan meyveler arasında mevîz-i sürh, mevîz-i siyah, âlû, zerd-âlû, incir-i lob, nârdenk ${ }^{4}$; İbrahim Paşa sarayına alınan meyveler arasında ise mevîz-i siyah, nârdenk, âlû-i turş, mevîz-i sürh, âlû, zerd-âlû ve incir-i lob ${ }^{5}$ bulunuyordu.

$\mathrm{Bu}$ dönemde yukarıda saydıklarımızdan başka Osmanlı sarayına dûd-ı $\operatorname{siyah}^{6}$; âlû-i siyah (siyah erik) ${ }^{7}$; kiras, nârenc-i turş, kestane-i Bursa, amrud, ceviz-i Rumî̀ ; çağla-i badem ${ }^{9}$; hurma, tüffâh (elma), kayısı-i tâze, vişne-i tâze, âlû-yı can (can ereği), limon, şeftalu, engür-i turş (ekşi üzüm), fıstık-1 iç, fındık, anâr-1 turş (ekşi nar), anâr-ı şîrin (tatlı nar) ve engür-i parmak (parmak üzüm) ${ }^{10}$ gibi meyvelerin de girdiğini görmekteyiz.

Yine 16. yüzyılda, III. Mehmed padişah olmadan önce şehzadeliği döneminde, 1002 senesi Cemâziye'l-âhiresi sonundan (21 Mart 1594) 1003 senesi Cemâziye'l-âhiresinin ilk haftasına kadar (21 Şubat 1595) geçen süre içinde Manisa sarayı mutfağına narenciyenin yanı sıra elma, armut, ayva, kiraz, kızılcık, vişne, siyah ve beyaz dut, üzüm, incir, erik, nar, şeftali, zerdali, kavun, karpuz ve zeytin; çerez ve tatlandırıcı olarak da kuru üzüm, incir, badem, fındık, fıstık, ceviz, kestane ve üzüm pekmezi satın alınmıştı ${ }^{11}$.

Bütün bunlar 16. yüzyıl ile 19. yüzyıl arasında, Osmanlı sarayında tüketilen meyvelerin günümüzdekinden pek farklı olmadığını ortaya koymaktadır. Buna göre Osmanlı sarayında tüketilen meyveleri, mevsimlere göre şu şekilde sıralamak mümkündür:

dâne, 4 dirhem kesdâne, 891,5 nârdeng-i Gelibolu, 22 kıyye kiras, 9 kıyye vişne, 56 kıyye emrûd-1 tâze ve 3 kıyye de kızılcık alınmıştır. Barkan, s.73-74.

3484 kıyye mevîz-i sürh, 726 kıyye mevîz-i siyah, 484 kıyye incir-i lob, 480 kıyye kayısı, 242 kıyye âlû-i siyah, 242 kıyye zerd-âlû ve 4.184 kıyye de nârdenk alınmıştır. Barkan, s.9.

${ }^{4} 220$ kıyye mevîz-i sürh, 275 kıyye mevîz-i siyah, 55 kıyye âlû, 55 kıyye zerd-âlû, 55 kiyye incir-i lob ve 110 kıyye nârdenk alınmıştır. Barkan, s.11.

${ }^{5} 4.740$ kıyye mevîz-i siyah, 480 kıyye nârdenk, 236 kıyye âlû-i turş, 50 kıyye mevîz-i sürh, 15 kıyye âlû, 15 kıyye zerd-âlû, 15 kıyye incir-i lob ve yine 590 kıyye mevîz-i siyah alınmıştır. Barkan, s.23-24.

6112 kıyye dûd-1 siyah için 224 akçe ödenmiştir. Barkan, s.80.

736 kantar ve 15 lodra âlû-i siyah için 4.124 akçe ödeme yapılmıştır. Barkan, s. 90 .

81.571 kıyye 23 tabla kiras, 6.809 adet nârenc-i turş, 121 kıyye kestane-i Bursa, 3.968 kiyye 100 kutu amrud, 26.200 adet ceviz-i Rumî alınmıştır. Barkan, s.112.

${ }^{9} 4$ sepet çağla-i badem için 64 akçe verilmiştir. Barkan, s.113.

${ }^{10} 49$ kıyye hurma, 580 kıyye 200 dirhem ve 26 kutu tüffâh, 86 kıyye 2 sepet kayısı-i tâze, 5 kıyye vişne-i tâze, 5 kıyye âlû-yı can, 900 adet limon, 80 adet 48 kıyye ve 1 sepet şeftalu, 258 akçelik engür-i turş, 43 kıyye fıstık-1 iç, 142 kıyye fındık, 1.460 kıyye anâr-1 turş, 3.941,5 kıyye anâr-1 şîrin ve 3.008 kıyye 200 dirhem engür-i parmak alınmıştır. Barkan, s.129.

"Feridun M. Emecen, "Şehzadenin Mutfağı: III. Mehmed' in Şehzadelik Döneminde Manisa Sarayına Ait Bir Mutfak Masraf Defteri", Soframız Nur Hânemiz Mamur Osmanlı Maddi Kültüründe Yemek Ve Barınak, (Editörler: Suraiya Faroqhi- Christoph K. Neumann), İstanbul 2006, s.117. 
İlkbahar: Elma, limon, erik çeşitleri (erik-i serfice, erik-i tâze, erik-i bardak, erik-i torba), çilek, kiraz, kayısı (kayısı-1 Acem ya da zerdali), incir, armut çeşitleri (emrud-1 akça, emrud-ı Mustafabey) ve üzüm çeşitleri (rezzaki, üzüm-i siyah);

Yaz: Şeftali, kızılcık, kavun, karpuz, erik, mürdümeriği, incir, kayısı (sonbahara kadar), armut (emrud-1 Bozdoğan), kiraz, üzüm, çilek;

Sonbahar: Üzüm-i çavuş, razzaki ve çekirdeksiz üzüm (Ocak'a kadar);

Kış: Elma, armut (emrud), ayva, ekşi ve tatlı nar, kestane, portakal, turunç, tatlı limon. Haziran'a kadar bulunan: portakal, ayva, kestane, turunç, $\operatorname{nar}^{12}$.

Saraya alınan yaş meyvelerin bir kısmı olduğu gibi tüketilmekteyse de, önemli bir kısmı kurularıyla birlikte Helvahâne'ye gönderiliyordu. Meselâ vişne-i tâze, kızılcık-1 tâze, zerdâlu, dut-1 siyah, fıstık içi, armud-1 tâze, kiras, anâr-1 şirin, anâr-1 turş ve şeftalu bunlardand ${ }^{13}$. Bu meyveler hoşaf, reçel ve turşu başta olmak üzere çeşitli yiyecek ve içeceklerin yapımında kullanılıyordu. Sarayda en çok tüketilen meyve türü üzümdü. Bilhassa kırsal alanların büyük bir kısmında tadlandırıcı olarak kullanılan bu meyvenin şeker oranının fazla olması, saraydaki tüketim miktarını da etkilemiştir. Kuru üzüm tüketimi yaşına oranla çok daha fazlaydı. Miktarları dönemden döneme değişmekle birlikte, tüketim sıralamasında üzümü nar, armut, elma, incir ve badem takip etmiştir ${ }^{14}$. Ayrıca bazı meyvelerden değişik yemekler de yapılmaktaydı. Meselâ bunlar arasında dolma-ı elma, dolma-ı karpuz ve dolma-1 ayva bulunuyordu. Ayva dolması halen Anadolu'nun bazı yörelerinde çok itibar görmektedir ${ }^{15}$.

Bunların yanında meyve kuruları, özellikle de üzüm, kuşüzümü, kayısı ve incir, bazen tâzeleriyle de karıştırılarak sıkça kullanılıyor, hatta sarayda misafirlere ikram edilen yemeklerin içine de konuyordu. Meselâ 17. yüzyılda yapılan kıymalı böreğin içine sadece et ve soğan değil kuru kayısı, kuşüzümü, hurma, kestane ve elma da katılmıştı. Az miktarda badem, kuru üzüm ve kuşüzümü gibi kestane de sevilen dâne malzemeleri arasındaydı. Ancak bu malzemeler, muhtemelen yemeklere lezzet katmak için kullanılmıştı ${ }^{16}$.

\footnotetext{
${ }^{12}$ Özge Samancı, "19. Yüzyılın İkinci Yarısında Osmanlı Elitinin Yeme-İçme Alışkanlıkları", Soframız, Nur Hânemiz Mamur Osmanlt Maddi Kültüründe Yemek Ve Barınak, (Editörler: Suraiya Faroqhi- Christoph K. Neumann), İstanbul 2006, s.198. Osmanlı sarayında Ilkbaharda tüketildiği ifâde edilen çilek, kiraz, kayısı ve bazı yeşil erik çeşitleri haricindeki bu meyvelerin bir çeşit ambardan geldiği, zira Osmanlı toprakları dâhilinde ilkbaharda üzüm ya da armut yetişen bölgenin bulunmadığı ifâde edilmektedir. Samancı, s.207, dipnot: 63 .

${ }_{13}^{13}$ Barkan, s.112-113.

${ }^{14}$ Arif Bilgin, Osmanlı Sarayının İâşesi (1489-1650), Marmara Üniversitesi Sosyal Bilimler Enstitüsü, (Basılmamış Doktora Tezi), İstanbul 2000, s.239.

${ }^{15}$ Hedda Reindl-Kiel, "Cennet Taamları, 17. Yüzyıl Ortalarında Osmanlı Sarayında Resmi Ziyafetler", Soframız Nur Hânemiz Mamur Osmanll Maddi Kültüründe Yemek Ve Barınak, (Editörler: Suraiya Faroqhi- Christoph K. Neumann), İstanbul 2006, s.65.

${ }^{i 6}$ Reindl-Kiel, s.74.
} 
Osmanlı mutfağında kullanılan meyvelerin 19. yüzyılda da pek fazla değişmediği görülmektedir. Aynı şekilde fındık ve meyve kuruları yemeklere lezzet katma amaciyla kullanıliyordu. Bazı et yemeklerine, tatlılara ve özellikle pilavlara fındık fıstık katılıyordu. 19. yüzyılın ilk yarısında en çok rağbet görenler badem, çam fistığı ve Şam fistığ1 idi. Yemeklere findik, ceviz ve kestane de konuyordu, fakat bunların daha az kullanıldığ1 görüllüyor. Bunlarla birlikte üzüm-i mürg veya üzüm-i kuş, çekirdeksiz üzüm ve bir çeşit beyaz üzüm olan razzaki de kullanılıyordu ${ }^{17}$. Bütün bunlar bize, Osmanlı insanının damak zevki konusuna nasıl bir çeşitlilikten hoşlandıklarını ortaya koymaktadır.

19. yüzyılda, Osmanlı sarayında da bol bol tâze ve kuru meyve tüketiliyordu. İstanbulluların sofralarına 20. yüzyılda eklenen muz, kivi ve ananas gibi egzotik meyveleri bir kenara bırakırsak, mutfak defterleri o dönemdeki meyvelerin bugün yediklerimizden pek farklı olmadığını ortaya koyuyor. Meyvenin kalitesini ortaya koyarken, nereden geldiği büyük önem taşıyordu ve menşeinin belirtilmesi marka gibi bir şeydi. Osmanlı sarayına giren üzümün veya eriğin dört beş çeşidi bulunuyordu ${ }^{18}$. Aynı meyvenin farklı türlerinin tüketilmesi, saray sâkinlerinin ince bir damak zevkinin olduğunu ve yemeklerinde çeşitlilikten hoşlandıklarını göstermektedir.

\section{Sarayda Tüketilen Meyvelerin Temin Edildiği Yerler}

Geniş bir coğrafyaya sâhip olan Osmanlı Devleti'nin sınırları içerisinde tabiî ki, çok değişik meyve türleri üretiliyordu. Ancak dönemin ulaşım şartları ile ülkenin çeşitli yerlerinde üretilen bu ürünlerin İstanbul'a getirilmesi öyle pek kolay işlerden değildi: Bilhassa, çabuk bozulmasından dolayı, pek çok yaş meyvenin İstanbul'a getirilmesi mümkün olmadığından, bunların kuruları getirilerek saraya alınyordu. $\mathrm{Bu}$ itibarla sarayın meyve ihtiyacı genellikle İstanbul ve yakın çevresinden karşılanmak zorundaydı.

Her dönemde İstanbul, yakın çevresiyle birlikte, meyve açısından oldukça zengin bir şehirdi. Kalabalık nüfusa sâhip bir şehrin, nakliye imkânlarının henüz çok sınırlı olduğu bir dönemde, bilhassa tâze meyve ihtiyacını yakın çevresinden karșılama zorunluluğu, bölgedeki meyve üretiminin gelișmesini teșvik etmiştir. İstanbul ve yakın bölgelerde yetişen her çeșit tâze meyve șehir halkının ihtiyacını karşıladı̆̆ gibi Osmanlı sarayinda da tüketilmekteydi ${ }^{19}$.

İstanbullunun beslenmesinde sebze ile birlikte meyve de büyük bir yer tutmaktaydı. Bu itibarla şehrin yakın çevresinde ve banliyölerinde sebze ve meyve bahçeciliği gelişmiş bir seviyedeydi. İstanbul'un Avrupa yakasındaki

\footnotetext{
${ }^{17}$ Samanc1, s.192.

${ }^{18}$ Samanc1, s.198.

${ }^{19}$ Bilgin, s.232.
} 
banliyösünde olduğu kadar Asya banliyösünde de çok sayıda bostan ve sebze bahçesi bulunuyordu. Fakat başkent civarının üretimi kentin ihtiyacını tamamıyla karşılamaya yeterli olmadığından bazı gündelik tüketim maddeleri ancak belirli eyâletlerden temin ediliyordu. Bundan dolayı da üretimin gerçekleștirildiği merkezlerle İstanbul arasında oldukça büyük bir deniz trafiği gelişmiști. Bu deniz trafiğine bir de kara trafiğ i eklenmiş; İstanbul'a at arabaları ve el arabalariyla da sebze ve meyve getiriliyordu ${ }^{20}$.

İstanbul'un sebze ve meyve ihtiyacının karşılandığ1 yerlerin daha çok şehrin varoșları ve şehre yakın bölgeler olduğunu ifâde etmiștik. Dayanıksız olan yas meyveler, șehirdeki hassa bahçeler ile șehir pazarlarının yanında, ağırlıklı olarak da Marmara'nın iki tarafındaki sahil kazalarından sağlanmaktaydi ${ }^{21}$. Bununla birlikte, biraz daha dayanıklı olan tâze meyveler ise, Amasya ve Ağriboz'u da içine alan geniş bir alandan tedârik ediliyordu ${ }^{22}$. Meselâ İstanbul'un banliyölerinden çeșitli meyveler; Doğu Trakya'dan üzüm; Bat1 Bitinya'dan kavun, karpuz, kestane; Batı Anadolu'dan kavun, karpuz, tâze meyve ve özellikle incir ve üzüm olmak üzere kuru meyveler; Karadeniz'in Anadolu kıyılarından fındık, kiraz, elma, kestane $^{23}$; Akdeniz adalarından ve Ege'den de gemilerle üzüm getiriliyordu ${ }^{24}$.

$\mathrm{Bu}$ merkezlerden başka İstanbul'un meyve ihtiyacının karşılandığ 1 daha başka merkezler de mevcûttu. Meselâ Vostica'dan siyah ve kırmızı üzüm; Gelibolu ve Atina'dan tâze üzüm; Alaiye'den kişniş üzümü; Kargun (Karg1) ve Ayaş'tan cinsi belirtilmeyen üzüm; İznikmid, Rodoscuk, Ağriboz, Gümülcine, Yenice-i Karasu, Siroz ve Vostica'dan badem; İzmir

\footnotetext{
${ }^{20}$ Robert Mantran, 17. Yüzyılın İkinci Yarısında İstanbul, C.I, (Çev: Mehmet Ali Kıliçbay, Enver Özcan), Ankara 1990, s.186.

${ }^{21}$ Meselâ Yalak Abâd ve Karamürsel taraflarından kiraz ve sâir meyve tedârik edilmekteydi. Buralardan getirilen kiraz ve diğer meyvelerin bazen tam olgunlaşmadan toplandığı ve yemenin mümkün olmadığı, bu sebeple Karamürsel ve sâir bağ, bahçe ve bostan olan mahallere adamlar gönderilerek meyvelerin tam olgunlaşmadan toplanmasının önlenmesi için gereğinin yapılması istenmektedir. Ahmed Refik Altınay, Onuncu Asr-l Hicrîde Istanbul Hayatl, (Haz: Abdullah Uysal), Ankara 1987, s.152.

${ }^{22}$ Bilgin, s.233.

${ }^{23}$ Mantran, s.187.

${ }_{24}$ İlber Ortayl, Osmanlt'yt Yeniden Kesfetmek, İstanbul 2006, s.81. Her y1l İzmir ve çevresinden kuru meyve temini için genellikle iki memur görevlendirilmekte; bu memurlar, Izmir ve çevresi kadılarının yardımıyla, muayyen miktardaki malları satın almakta ve parasını da buradaki mukataalardan karşılamaktaydılar. Memurlar, İzmir ve çevresinden temin ettikleri malları, İzmir limanındaki depolarda (mahzen) toplayarak deniz yoluyla İstanbul'a gönderiyorlardı. Bilgin, s.139. Ancak bazı dönemlerde İzmir ve çevresinden satın alınan ürünlerin zamanında İstanbul'a ulaşmamasından dolayı sıkıntı çekildiği ve bunun önlenmesi için İzmir ve Ayazmend kadılarına hükümler gönderildiği görülmektedir. Bu hükümlerde bazı matrabâz tâifesi zuhûr edip, İstanbul'a lâzım olan kara üzüm, razakı, incir ve bunun emsâli zehâyiri der-mahzen edip İstanbul'da sıkıntı çekilmeyince getirmemek ile büyük sıkıntı çekildiğinden, satın alınmış zahireyi der-mahzen ettirmeyip vakt ve zamanıyla gemilere yüklettirip, İstanbul'a gönderilmesi emredilmiştir. 26 Ramazân 995 / 30 Ağustos 1587. Altinay, s.150.
} 
çevresinden armut; Ağriboz, Bursa ve Lapseki'den karpuz; Lefke ve Edirne'den ayva; Midilli'den fıstık; Gemlik ve Bozüyük'ten nar ve yine Bursa'dan alı̨̧ ve koruk $^{25}$; Diyarbekir'den de erik ve kişniş üzümü ${ }^{26}$ getiriliyordu. Ayrıca Kânûnî ve III. Murâd zamanlarında, Alanya ve Trablusşam'dan muz getirildiği ifâde edilmektedir ${ }^{27}$. gelince:

İstanbul'a getirilen bu yiyeceklerin Osmanlı sarayına nasıl girdiğine

Sarayın ihtiyacı için İstanbul piyasasından alınan mallar değişik kanallardan temin ediliyordu. Bu kanallar kapanlar, pazarlar, bakkallar, doğrudan bir kısım üreticiler veya belli şahıslardı. İstanbul'un limanları bu yüzden olabildiğince hareketliydi. Başkente dışarıdan gelen mallar, cinslerine göre, farklı iskelelerde boşaltılmakta ve gerekli işlemler yapıldıktan sonra şehir esnafına dağıtılmaktaydı. Kavun, karpuz ve üzüm gibi meyveler Eminönü, Hisar iskelesi, Zindankapı ve Yemiş iskelesinde boşaltılıp Muhtesip çardağı karşısına götürülüyor ve orada dağıtımı yapılıyordu. Mısır'dan gelen mallar ise Arap iskelesindeki boş bir araziye boşaltılıyor, dağıtım buradan gerçekleştiriliyordu. Kuzey Marmara ve Trakya'dan getirilen ürünler de Ayazmakapı iskelesinde boşaltılıyordu ${ }^{28}$.

Sarayın ihtiyacı olan meyveler, şehir pazarlarından veya doğrudan üreticiden alındığ gibi, bunların temin edildiği önemli yerlerden biri de hassa bahçelerdi ${ }^{29}$. Bostancıbaşının nezaretinde, binlerce bostancının çalıștığ bu bahçelerde yetiştirilen meyve ve sebzeler tamamiyla sarayda

25 15-17. yüzyıllar boyunca İstanbul'un meyve ihtiyacının nerelerden karşılandığı ve nerelerden meyve geldiği konusunda daha geniş bilgi için bkz. Bilgin, s.233-237.

${ }^{26}$ Bilgin, s.134.

${ }^{27}$ Bilgin, s.238. İstanbul'a ulaşan yaş meyvelerin düzenli bir şekilde halka ulaştırılması için İstanbul kadısına çeşitli hükümlerin yollandığ 1 görülmektedir. Bu hükümlerde yaş meyve ile İstanbul'a gelen gemileri bazı kimselerin yollarda karşılayı iskeleye gelmeden getirdikleri yemişi kendileri satın alıp, adâlet ve kânûn üzere halka ve pazarcılara adâletle taksîm ve tevzî̀ ettirmedikleri ifâde edilerek bunların engellenip, yaş meyve ile İstanbul'a gelen gemileri kimseye karşılatmayıp iskeleye gelip, getirdikleri meyveyi halka ve pazarcılara adâlet ve kânûn üzere satmalarının temin edilmesi emredilmiştir. 11 Muharrem 968 / 2 Ekim 1560. Altınay, s.118.

${ }^{28}$ Bilgin, s.114-115.

${ }^{29}$ Hassa bahçeler hakkında Tavernier şöyle demektedir: "Bugüne kadar gelen eski bir gelenek veya kanun, Osmanll sultanlarınin yiyecek ihtiyaçların, bu bahçelerden elde ettikleri gelirlerle gidermelerini gerektirir. Bu yüzden, sultana âit İstanbul'un Avrupa ve Asya yakasında deniz klyısı boyunca birçok bahçe vardır. Sarayın çeşitli bölümlerinde, çok miktarda çiçeğin olduğu kü̧̧ük bahçeler görünür. Özellikle de bu tür bahçeler padişahın ve süphesiz hanım sultanların dairelerinde bulunur. Sultanın bahçelerinin ve Topkapt Sarayt'nın bahçesinin kâhyası bostancıbaşıdır. Etrafı servilerle çevrili yollardan oluşan Topkapl Sarayı'nın bahçesi, sarayın en büyük bölümüdür. Ama buraya fazla özen gösterilmemiş ve çoğu yerini dikenler kaplamıştır. Ĕ̆ger padişahın bahçeye çıkacă̆ bilinirse, bostancllar gelip, onun geçeceği yolları temizlerler. Bu yolların dışındaki yerler, sebze veya meyve bahçeleriyle doludur. Çok miktarda çiçekler, frambuazlar ve salataliklar yetiştirilir". J. B. Tavernier, Bir Fransız Seyyahın Gözüyle Topkapı Sarayı'nda Yaşam, Büyük Senyörün Sarayı, (Çev: Haluk Yanardağ), Istanbul 2005. s.175. 
tüketilmiyor, bir kısmı șehir esnafına satılmak suretiyle padișahın günlük giderleri karşılanıyordu. Padişahın kendi bahçelerinin ürünleri olmalarına rağmen, saray mutfağına alınan bu mallara ücret de ödeniyordu. Saray mutfağının ihtiyacı karșılandıktan sonra, hassa bahçelerden elde edilen sebze ve meyvelerin fazlası piyasaya satılıyordu ${ }^{30}$. Hassa bahçelerden saraya alınan meyveler arasında kiraz, armut, üzüm, elma, aluç, ayva, tâze kızılcık, ekși ve tatlı nar ile tâze ceviz gibi meyveler bulunuyordu ${ }^{31}$.

\section{Osmanlı Sarayının Çiçek İhtiyacı}

Osmanlı sarayına alınan i'âşenin içinde çeşitli sebze ve meyvelerin yanında çiçeklerin de bulunduğu görülmektedir. Saraya alınan bu çiçeklerin ne için kullanıldığı pek belirtilmezken, bunların genellikle saray mutfağının helvahânesinde kullanıldığı anlaşılmaktadır.

Barkan tarafından yayınlanan saray mutfağ 1 masraf defterlerinde 981 Muharremi ile 982 Muharremi arasinda (5 Mayıs 1573-24 Nisan 1574) geçen bir yıllık dönem içinde matbah-1 âmireye alınan çiçekler arasında șükûfe-i benefșe ve șükûfe-i șeftalu ${ }^{32}$ geçmektedir ki, bunlarmn ne için kullanıldığı ifâde edilmemiştir. Ancak bunların kıyye ile ve saray mutfă̆ına alınması, bazı tatlı ve reçel yapımında kullanıldığını düşündürmektedir.

Yine aynı dönem içinde helvahâne-i âmireye benefşe-i huşk (kuru menekşe), benefșe-i tâze ${ }^{33}$ ve şükûfe-i zerrinkadeh ${ }^{34}$; Üsküdar sarayı mutfağına da şükûfi-i babûnec ${ }^{35}$ alınmıștır. 1011-1012 (12 Mayıs 1063-29 Mayıs 1064) tarihleri arasında ise saray-1 atîk-i âmire mutfağı için varak-1 benefşe (menekşe yaprağı), nilüfer ve şükûfe-i karakaş ${ }^{36}$ alındığı kaydedilmiştir. Herhalde kuru menekșe ve menekşe yaprakları sarayın mutfağında yemeklerde veya tatlılarda kullanılmıyordu. Çünkü menekșe yaprağının karşısında bulunan "berâ-yı eşribe" notu, bu çiçek ve yapraklarının çay gibi içilmek için alındığını ortaya koymaktadır.

Saraya alınan bu çiçeklerin nerelerden temin edildiğine gelince: Bunlar genellikle piyasadan ve pazarlardan alınırken ${ }^{37}$, pek çoğu da hassa

\footnotetext{
${ }^{30}$ Bilgin, s.117.

${ }^{31}$ Bilgin, s.117.

${ }^{32} 206$ kıyye 200 dirhem şükûfe-i benefşe için 2.408 akçe ve 2 kıyye 200 dirhem şükûfe-i șeftalu için de 25 akçe ödenmiştir. Barkan, s.113.

${ }_{33} 20$ kıyye benefşe-i huşk için 1.190 akçe ve 30 kıyye benefşe-i tâze için de 360 akçe ödenmiştir. Barkan, s.120.

${ }^{34}$ Barkan, s.121.

35300 dirhem şükûfi-i babûnec için 20 akçe verilmiştir. Barkan, s.135

3674 kıyye varak-1 benefşenin her kıyyesi için 40 akçeden toplam 3.000 akçe; 56.300 adet nilüferin her 2 adedi için 1 akçeden 28.150 akçe; 20 kıyye şükûfe-i karakaşın her kıyyesi için de 20 'akçeden 400 akçe ödenmiştir. Barkan, s.158

${ }^{37}$ Meselâ 981 yılı içerisinde matbah-1 âmire için 206 k1yye 200 dirhem şükûfe-i benefşe, 2 kıyye 200 dirhem şükûfe-i şeftalu, 249 kıyye verd-i sakız ve 819 kıyye de şükûfe-i ahmer alındığı görülmektedir ki, bunların tatlı ve reçel yapımında kullanıldığı düşünülmektedir.
} 
bahçelerden temin ediliyordu. Hassa bahçelerden saraya alınan mallar arasında meyve ve sebzelerin yanında bazı bitkilerin çiçekleri ve yaprakları da dikkat çekmektedir. Saray bahçelerinden sarayın tüketimine sunulan belli başlı çiçekler arasında şükûfe-i benefşe (menekşe çiçeği), şükûfe-i şeftali (şeftali çiçeği), verd-i ahmer (kırmızı gül) ve verd-i sakız (sakız gülü) bulunuyordu ${ }^{38}$.

Saray mutfağına alınan bu çiçeklerin bazı tatlı ve reçellerin yapımında kullanıldığını söylemiş̧tik. Ancak saraya alınan tüm çiçeklerin bu şekilde değerlendirildiği düşünülmemelidir. Zira alınan çiçekler, biraz sonra vereceğimiz listelerde de görüleceği üzere, bazı özel günlerde padişaha, sarayın ileri gelen görevlilerine, haremde bulunan padişah kadınlarına ve hatta ileri gelen devlet adamlarma gönderiliyordu.

Böylece saraya alınan çiçeklerin iki şekilde değerlendirildiği ortaya çıkmaktadır. Bu yollardan birincisi saray mutfağında çeşitli tatlı ve reçel yapımında kullanmak, ikincisi de resmî ve özel günlerde padişah ve önemli kimselere göndermekti. Bu itibarla sarayın çiçek ihtiyacını karşılamak için, bilhassa İstanbul ve çevresi ile hassa bahçelerde çeşitli çiçek yetiştiriciliğinin geliştiği görülmektedir. Bu bahçelerde yetiştirilen süs çiçekleri arasında gül, menekşe ve şebboyun yanı sıra karanfil, lâle, nergis, sümbül, süsen ve zambak gibi çiçekler de bulunuyordu ${ }^{39}$.

Osmanlı döneminde yetiştirilen en önemli çiçeklerden birisi güldü. Fatih Sultan Mehmed döneminde yapılan Yeni Saray'ı (Topkapı Sarayi) kuzey, batı ve doğu yönünden çevreleyen "Hasbahçe"nin bir bölümünde, saray mutfaklarının ihtiyaçlarını karşılamak amacıyla gül (kırmızı gül ve sakız gülü) yetiştiriliyordu. Bundan dolayı da bölgeye "Gülhâne" (Gülhâne Parkı) adı verilmiştir. Bu bahçede yetiştirilen güllerden sarayın ihtiyacı olan gül suyu ve gülbeşeker hazırlandığ 1 tahmin edilmektedir ${ }^{40}$. Hassa bahçelerin gülfidanı ihtiyacının ise öncelikle Edirne ve çevresinden temin edildiği anlaşılmaktadır. Bu itibarla değişik tarihlerde, Edirne bostancıbaşısı ve kadısına, gülfidanı tedarik ederek göndermesi hususunda fermânlar gönderilmiştir ${ }^{41}$.

\footnotetext{
Barkan, s.113.

${ }^{38}$ Bilgin, s.117.

${ }^{39}$ Burhan Baytop, Türkiye'de Eski Bahçe Gülleri, Ankara 2001, s.XII.

${ }^{40}$ Baytop, s.5.

${ }^{41}$ Meselâ 995 Zilhicce / 1587 Kasım'ında Edirne'de bulunan bostancıbaşıya gönderilen hüküm ile 'İstanbul'da vâki olan Dârü's-Sa'âde-i Atîk Bahçesi içün gül lâzım olmağın, olageldiği üzere Edirne'den gül ihrâc ettirilip gönderilmek emredip adet-i kadîm üzere lâzım olan akça verilmiştir. Buyurdum ki, vardikda te'hîr ve tevakkuf eylemeyip, gereği gibi mukayyed olup simdiye değin tedârik olunduğu üzere gül fidant tedârik eyleyip beygirlere tahmil edip Südde-i Saadetime gönderesin, ihmal ve müsâheleden hazer eyleyesin" denilmektedir. Altmay, s.20.13 Zilhicce 1001/10 Eyluil 1593 tarihinde Edirne kadisına ve Edirne bostancibaşısina gönderilen bir başka hükümde de, "Südde-i sa'âdetimde Hassa bağçeleriçün kadîmden gönderildiği üzere dörtyüz kantar kırmızı gül ve üçyüz kantar sakız
} 
Çok değişik türleri üretilen tezyinat güllerine genellikle Arapça veya Farsça isimler veriliyordu: Gül-i sadberg ${ }^{42}$ (Yüz yapraklı gül), Gül-i rânâ (Güzel gül), Gül-i zîbâ (Süslü gül), Verd-i handan (Gülen gül) ve Verd-i Muhammedî (Peygamber gülü) bunlardan sadece birkaçı idi ${ }^{43}$. Bu çiçekler sarayın bahçelerinde de yetiştiriliyordu. Meselâ metni verilen 1154 senesi Muharremine ait listede, ekstradan ortaya çıkan harcamalar arasında, 29 Muharrem 1154 tarihinde Şehzâdebaşı'ndaki konağın bahçesi için her biri 80 'er akçeden olmak üzere 37 adet sadberg gülü dağarı (çanak, çömlek) alınması, bu çiçeklerin saray bahçelerinde de üretildiğinin bir göstergesidir.

Saray bahçelerinde güllerin yanı sıra sümbüller de yetiştiriliyordu. Hassa bahçelerde yetiştirilen bu çiçeğin de büyük önem arz ettiği ve bu sebeple çeşitli yerlerden sümbül soğanı istendiği görülmektedirr ${ }^{44}$.

Osmanlı toplumunda yetiştirilen önemli çiçeklerden biri de, millî çiçeklerimiz arasında sayılan karanfildi. Karanfilin pek çok değişik türü elde edildiği gibi Avrupa'da bile bu kadar çeşidi olmayan bu çiçeğe, çok güzel isimler de verilmişti" ${ }^{45}$. Eski çiçek meraklılarının "Hayâl-i merâm, Ruh-1

gülü fidanı gönderilmesin emr idüb buyurdum $k i$, vusûl buldukda emr-i celîlü'l-kadrim mucibince kadîmden gönderildiği üzere dörtyüz kantar kırmızı gül ve ü̧̧yüz kantar sakız gülü fidant mu'accelen tedârik olub vakt ve zamant ile kira davarlarina tahmîl olunub südde-i sa'âdetime gönderesin ihmâl ve müsâhele eylemeyesin" diye emredilmiştir. Baytop, s.5.

${ }_{42}$ Gül-i sadberg, yüz yapraklı gül demek olup Okka gülü, Has gül, Hokka gülü, Reçel gülü, Sadberg gülü veya verd-i sad-berg gibi değişik isimlerle de anılmaktadır. Bu gül ilkbahar ve sonbaharda olmak üzere yılda iki defa açar. İki metre kadar yükselebilen gülün çiçekleri katmerli, pembe renkli ve kuvvetli kokuludur. Osmanlı döneminde büyük bir beğeneni kazanmış olup gül suyu ve gül reçeli hazırlanmasında kullanılmıştır. Baytop, s.74. Bu gülün menșei Ánadolu olup ulemâ ve fuzalâ tarafından dahi pek ehemmiyetli telakki edilmiştir. Meselâ 1000 tarihine doğru gelen "Künhü'l-Ahbar" sahibi Defterdâr Âli Efendi kendisinin yüz adet şiirini ihtivâ eden divânçesine "Gül-i Sad-berg" adını verdiği gibi Şeyhülislâm Bostan-zâde Yahya Efendi de kendi telif ettiği bir risâlesine aynı șekilde "Gül-i Sad-berg" adını koymuştur. N. Hikmet Polat, Türk Çiçek Ve Ziraat Kültürü Úzerine, Cevat Rüştü'den Bir Güldeste, İstanbul 2001, s.120. Ayrıca bu çiçek hakkında bilgi için bkz. Polat, s.121.

${ }^{43}$ Baytop, s.5. Güller hakkında daha geniş bilgi için bkz. Polat, s.111-146.

44 Meselâ 18 Rebiyülâhir $987 / 14$ Haziran 1579 tarihinde Haleb'e tâbi' Üzeyir beyine gönderilen bir hükümde: "Bahçelerim mühimmî için 500 bin adet sünbül soğanı lâzım olmağın, tahsîl içün Hassa Bahçeleri'm Oda Başıları'ndan Korkut Odabaşı irsal olunmuşdur. Buyurdum ki, vardikda teahhür etmeyip civâr-l mezbûrda bulunan mahallerde gayet alâsından 500 bin adet sünbül soğanların tahsîl edip, mezbur Odabaşıya teslim etdirip, eğlendirmeyip emr olunan mikdarı soğanlar ile ber-vech-i isti'câl irsâl etmek üzere olasın. Bu bâbda Haleb Defterdârı'na dahi masraf için lâzım olan akçayı Haleb hazinesinden veresin" diye emr olunmuştur. Altınay, s.11. Ayrica 13 Muharrem 1001 / 20 Ekim 1592 tarihinde Maraş beyine gönderilen bir başka fermân ile de Has bahçede sümbül soğanı azalmış olmakla, Maraş'ın dağ ve yaylaları sümbül yeri olduğundan ellişer bin ak sümbül ve gök sümbül soğanları yollanması istenmiştir. Başbakanlık Osmanlı Arşivi, Mühimme Defteri, C.69, Sıra no: $177, \mathrm{~s} .89$

${ }_{45}$ Meselâ beyazlardan ikisine "Nûr-1 sefîd ve Necm-i seher" denildiği gibi şeker renkli beyazlardan ikisine de "Bedr-i bahar ve Nûr-1 gülş̧en" adı verilmişti. Bunlardan başka "Cihanfeza, Elmaspâre, Tasvîr-i gülş̧en, Bedr-i münir, Gülçin-i cedîd, Rû-yı niyâz, Kayser-i şems, Gülzâr, Gümüş fincan, Gülçin, Kapucı alı, Kırçıl al, Kumkapı alı, Fideli leylak, Pertev-i elmas, Karanfil, Tasvîr-i hayâl, Tasvîr-i aşk, Hayâl-i merâm, Dil-ârâ, Şems-i kudred, Şevk-i mücessem, Aşk-1 mücessem ve Nûr-1 mücessem" gibi daha pek çok isim bunlar arasındadır. 
gülren, Şem“-i münîr, Mâhitâb-1 cedîd, Mağribî, Mihr-i münîr, Nakş-1 riyâz, Aşk-1 mücessem ve Tasvîr-i aşk" gibi isimler verdikleri karanfil, Garp'ta saf ve şiddetli bir aşkı temsil ediyordu ${ }^{46}$.

Yukarıda ifade edildiği gibi 17. ve bilhassa 18. yüzyılda, Osmanlı Devleti'nde değişik çiçeklerin yetiştirilmesine büyük önem verilmişti. Bunların en önemlisi bilindiği gibi lâledir. Osmanlı tarihinde kendi ismiyle koca bir devir açan bu millî çiçeğin tarihi ve menşei hakkında oldukça ihtilâf vardır. Bazıları bu çiçeğin asıl vatanını güney Avrupa ve Asya olarak gösterirken, bazıları da İran olduğunu söylerler. Şurası açıktır ki, bu çiçek Garp, Avrupa çiçeği olmaktan ziyade bir Şark çiçeğidir. Hele tarihimizdeki hususiyeti hasebiyle bu çiçek büyük bir merakla yetiştirilmiş, birçok türleri elde edilmiştir ${ }^{47}$.

Osmanlı döneminde lâle, İstanbul'a IV. Mehmed zamanında Avusturya sefîri Schmith Fon Schvarnhorn tarafından getirilmişti. Daha evvel de IV. Murad'ın Bağdat seferi dönüşünde müverrih Koca Hasan Efendi vasıtasıyla temin edilmişti. Lâle Devri'nde Damat İbrahim Paşa çiçekleri çok sevdiğinden lâlenin yayılmasına son derece gayret etmişti. O derecede ki, Hollanda'dan getirilen lâleye "Lü'lü-i erzak" adı verilmiş ve İbrahim Paşa bu lâleden yetiştirenlere mükâfatlar dahi vaad eylemişti. Bu lâle türü daha çok Çırağan ve Neşatâbâd bahçelerinde yetiştirilir ve o kadar özen gösterilirdi ki, hava sıcak olduğu zamanlar renkleri uçmasın diye üzerine beyaz örtüler bile örtülürdü ${ }^{48}$.

Lâle, III. Ahmed devrinde çiçek sevenlerin zevkleri arasında özel bir yere sâhipti. Hiçbir çiçek, hiçbir zaman bu kadar çok sevilmemiş, bu kadar çok yüceltilmemişti. Lâle bu devirde o kadar çok sevilmişti ki, ayrı bir lâle edebiyatı vücuda getirilmişti ${ }^{49}$. Bunun yanında karanfilde olduğu gibi lâlenin de pek çok çeşidi yetiştirilmiş ve bu çiçeğe de çok değişik isimler verilmişti ${ }^{50}$. Osmanlı döneminde pek çok değişik çiçeğin yetiştirilmesi ve bunlara çok güzel isimler bulunarak verilmesi, Osmanlı halkının ve bilhassa saray mensuplarının çiçeklerden hoşlanan ince bir ruha sâhip olduğunun göstergesidir.

\footnotetext{
Polat, s.62-63.

${ }^{46}$ Polat, s.55.

${ }^{47}$ Polat, s.73.

${ }^{48}$ Polat, s.74. Aynı bilgi s.89' da da bulunmaktadır.

${ }^{49}$ Polat, s.67.

${ }^{50}$ Lâle isimleri için ayrıca bir lugatçe bile yapılmıștı. Meselâ yalnız "elif" harfi ile başlayan lâle isimleri arasında bile yüzlerce isim bulunmaktadır. Bunlardan bazıları şunlardı: "Ấb-1 kevser, ÂAb-1 yâkût, Ebû'l-feyz, Ebr-i hûbân, Âteş-i aşk, Âteş-i şevk, Âsâr-1 ikbâl, Âsâr-1 merâm, Âsâr-1 saâdet, Âsâr-1 izzet, Âsâr-1 inâyet, Ecmel-i ezhâr, Ahter-i bahâr, İhsân-1 kudret, İhsân-1 vedûd, İhsân-1 Yezdân, İhsân-1 Bârî, Esrâr-1 Yezdân, Esrâr-1 İlâhi, Esrâr-1 tecelli, Esrâr-1 Hak, Âşüfte-nümâ,, Âşüfte-dil, Âşüfte-i elmas, Âfitâb-ı çemen, Âfitâb-1 gülzâr, İkbâl-i saâdet, İksîr-i kudret, İksîr-i inâyêt, İmdâd-1 rûhânî, Envâr-1 irem, Envâr-1 feyz, Âh-1 üftâde, Aksâ-yı merâm, Âsûb-1 gülzâr, Âşûb-1 devrân, İkrâm-1 Hak, İhsân-1 Hüdâ, Âyine-i gülşen, Âyine-i Cemâl". Polat, s.63-64.
} 


\section{Listelerin Değerlendirilmesi}

Yukarıda verilen ön bilgilerden sonra artık listeleri incelemeye geçebiliriz. Bu çalışma Başbakanlık Osmanlı Arşivi'nde (BOA) bulunan 18. yüzyıla âit iki ayrı listeye dayanılarak hazırlanmıştır. Bunlar, birincisi Cevdet Saray, no. 2608'da kayitli olan 1-30 Muharrem 1154 (19 Mart-17 Nisan 1741), ikincisi de Cevdet Sarây, no. 2354'de kayıtlı 1-30 Ramazân 1158 (27 Eylül-16 Ekim 1745) tarihli Osmanlı sarayının birer aylık meyve ve çiçek masraflarının kaydedildiği listeleridir.

Önce, her iki listenin ortak özellikleri hakkında bilgi verelim. Öyle anlaşılıyor ki, Osmanlı sarayına alınan meyve ve çiçeklerin masraf kayıtları birer aylık dönemler halinde düzenlenmektedir. Belgeler üç ana bölümden oluşmuştur. Belgelerin birinci bölümünde o ay içerisinde saraya alınan meyve ve çiçeklerin mutâd günlük dökümleri yapılmıştır. Ayların 1'inden 30 'una kadar olan günler sırasıyla kaydedilerek her gün saraya ne kadar meyve ve çiçek alındığı, bunların birim fiyatları ve hammâliyeleri de kaydedilmiştir. Bu bölümün sonunda ise sarayın bir aylık mutâd meyve ve çiçek masrafının yekûnu akçe ve guruş olarak verilmiştir.

Belgelerin ikinci bölümünde ise zuhûrâta bağlı olarak ortaya çıkan meyve ve çiçek masraflarının kaydedildiği görülmektedir. Burada, her gün olmamakla birlikte, bazı günler ekstradan ortaya çıkan masraflar kaydedilmiştir. Genellikle bazı özel günlerde şeyhülislâma, hazînedâra, dârüssaâde ağasına, padişah kadınlarına ve sarayın önemli görevlilerine gönderilen meyve ve çiçeklerin dökümleri burada yapılmıştır. Biraz sonra ayrıca değerlendirileceği gibi, nevrûz ve arîfe günlerinde hem sarayın ileri gelenlerine hem de padişahın yakını olan sultan hazerâtına gönderilen meyve ve çiçeklerin dökümleri de buradadır. Bütün bunların yanında, İstanbul'da bulunan çeşitli devletlerin elçilerine gönderilen meyve ve çiçeklerin masrafları da buraya kaydedilmiştir.

$\mathrm{Bu}$ bölümün sonunda ise sarayın zuhûrâta bağlı olarak ortaya çıkan meyve ve çiçek masrafları, bunların hammâliyeleri ile taşıma ücretleri de ('akkâma verilen) yine burada yekûn olarak verilmiştir. Bu bölümün en sonunda ise günlük mutâd masraflar ile zuhûrâta bağlı olarak ortaya çıkan masraflar toplanarak kaydedilmiştir.

Belgelerin üçüncü bölümünde ise hazînedâr ağaya hitâben yazılan bir not bulunmaktadır ki, genellikle o aya âit meyve ve çiçek masrafının ne kadar tuttuğu izah edildikten sonra bunun hazineden ödenerek masraf defterine kaydedilmesi istenmiştir.

Listelerde verilen meyve sepetleri ile çiçek tablalarının içinde nelerin bulunduğunun kaydedilmemiş olması, araştırmanın kapsamı bakımından bir eksiklik sayılabilir. Ancak yukarıda verilen bilgiler ışığında, bu sepetlerin ve 
tablaların içinde nelerin bulunabileceği hakkında çeşitli tahminler yürütmek mümkündür. Meselâ birinci listenin âit olduğu dönem (19 Mart-17 Nisan 1741) kış mevsiminin henüz bittiği ve ilkbaharın da yeni başladığı bir zaman dilimine rastlaması itibarıyla, yaş meyvenin oldukça zor bulunduğu bir dönemdir. Ancak yine de bu sepetlerin içinde elma, armut, ayva, ekşi ve tatlı nar, kestane gibi kıştan kalan ve uzun süre dayanabilen meyvelerin yanında, bu mevsimde kolayca bulunabilen portakal ve turunç gibi meyvelerin de olduğu tahmin edilebilir. Bununla birlikte, yaş meyvelerin yanı sıra kuru meyvelerin bulunması ihtimali de yüksektir. İkinci listenin ait olduğu dönem ise (27 Eylül-26 Ekim 1745) sonbahar mevsimi olması hasebiyle satın alınan meyve sepetlerinin içinde daha çok üzüm çeşitleri ile elma ve armut gibi meyvelerin olduğu düşünülebilir.

Her iki listede verilen çiçek tablalarında bulunan çiçekleri tahmin etmek ise belki biraz da kolay olacaktır. Çünkü verilen listelerde çiçekler hakkında herhangi bir bilgi bulunmamasına rağmen, iki listenin de Lâle Devri'nin hemen akabinden gelen bir döneme âit olması hasebiyle, çiçek tablasında çok değişik çiçeklerin bulunması ve bunlar arasında bilhassa lâlelerin oldukça önemli bir yer tutması kuvvetle muhtemeldir. Tabiî ki, bu tablaların fiyatlarına bakıldığında 480 akçe gibi yüksek bir rakam göze çarpmaktadır. Bu da, bu dönemde, Osmanlı Devleti'nde çiçek yetiştiriciliğinin önemli bir geçim kaynağı olduğunu ortaya koymaktadır.

$\mathrm{Bu}$ bilgileri verdikten sonra şimdi de belgelerin içeriklerini değerlendirmeye geçebiliriz. Burada her iki belgenin içeriği birbirinden bağımsız olarak incelenecektir.

1-30 Muharrem 1154 tarihine âit olan birinci listede, 1 Muharrem Cumartesi $^{51}$ gününden başlamak üzere otuz günlük meyve ve çiçek masrafi kaydedilmiştir. Buna göre Osmanlı sarayına her gün 51 sepet meyve ${ }^{52}$ ve Pazartesi ile Cuma günleri olmak üzere haftada iki gün üçer tabla ${ }^{53}$ da şükûfe (çiçek) alınmıştır. 1154 senesi Muharrem ayında saraya mutâd olarak alınan toplam meyve miktârı 1530 sepettir. Bu sepetlerin birim fiyâtı ise 45 akçedir. Buna göre sarayın bir aylık mutâd meyve masraf1 68.850 akçe olarak kaydedilmiştir. Sarayın otuz günlük çiçek tüketimi ise 24 tabla, birim fiyatı da 480 akçe olup toplam miktâr 11.520 akçe olarak verilmiştir. Tabiî ki, bu

\footnotetext{
${ }^{51}$ Bütün tarih çevirme kılavuzlarında 1 Muharrem 1154 tarihi, Pazar olarak verilmesine rağmen, burada Cumartesi olarak kaydedilmiştir. Bunun sebebinin ise, listenin sonradan düzenlendiği ve kâtip tarafından günün sehven Cumartesi olarak yazıldığı tahmin edilmektedir.

${ }_{52}$ Listelerde sepetlerin ağırlı̆̆ 1 hakkında bilgi verilmediği gibi bu sepetlerin içinde hangi meyvelerin olduğu hakkında da bir şeyden bahsedilmemiştir. Ayrıca burada kullanılan sepet hakkında bilgi veren herhangi bir kaynağa da rastlayamadık.

${ }^{53}$ Çiçek tablası hakkında da herhangi bir bilgi bulunmamaktadır. Ancak fiyatının 480 akçe gibi çok yüksek bir rakam olmasından, içerisinde değişik çiçeklerden meydana gelen bir aranjman olduğu tahmin edilmektedir.
} 
meyve ve çiçeklerin bir de taşıma ve hammâliyesi olacaktır. Bu kaleme giden masraf ise toplam 407 kişilik işçi grubuna kişi başına 15'er akçeden 6.105 akçe ödenmiştir. Böylece sarayın aylık mutâd meyve, çiçek ve hammâliye masrafı yekûn olarak 86.475 akçeyi bulmuştur. Akçe olarak verilen masraf, 1 guruş 120 akçe hesabı üzere, guruşa çevrilmek suretiyle verilmiş ve sarayın bir aylık mutâd meyve ve çiçek masrafı 720,5 guruş olarak hesaplanmıştır.

1154 senesi Muharremine âit listenin zuhûrâta bağh olarak ortaya çıan ekstra harcamalarına gelince: Bu bölümde yapılan harcamaları iki ana başlık altında değerlendirmek mümkündür. Birinci grubu tek tek şahıslara gönderilen meyve ve çiçek masrafları oluştururken, ikinci grubu ise özel günlerde toplu halde alınan meyve ve çiçek masrafları meydana getirmektedir.

Buna göre; 1 Muharrem 1154 günü Hazînedâr Ağa'ya Mehter Mehmed yediyle 12 sepet dökme meyve ve 1 tabla da çiçek alınmıştır. Dökme meyvenin sepeti 70 akçe ve çiçeğin tablası da 480 akçe olduğuna göre, Hazînedâr Ağa için alınan meyvenin ücreti 840 , çiçeğin ücreti de 480 akçe olup toplam masraf 1.320 akçeyi bulmuştur.

2 Muharrem 1154 tarihinde şeyhülislâm ${ }^{54}$ için alınan meyve ve çiçeğe ise bundan çok daha fazlasının ödendiği görülmektedir. Şeyhülislâm için 40 sepet dökme meyve, 5 tabla da çiçek satın alınmıştır. Buna göre meyve için 2.800 akçe, çiçek için de 2.400 akçe ki, toplam 5.200 akçe ödenmiştir.

5 Muharrem 1154 tarihinde yeni Fransa elçisi İstanbul'a geldiğinde Galata'ya 40 sepet dökme meyve ile ( 2.800 akçe) 5 tabla çiçek ( 2.400 akçe) gönderilmiş, bunların taşınması için 15 adet 'akkâmına 45'erden 675 akçe ve 6 adet kayığına da kayık başına 60'ar akçe olmak üzere 360 akçe ödenmiştir. Böylece İstanbul'a yeni gelen Fransa elçisi için harcanan miktâr 6.235 akçeyi bulmuştur.

12 Muharrem 1154 tarihinde ise, hem İstanbul'da bulunan İan elçisine hem de Moskov elçisi Galata'ya geldiği günün ertesinde gönderilen meyve ve çiçek masrafı verilmiştir. Her iki ülkenin elçilerine '40'ar sepetten 80 sepet

\footnotetext{
${ }^{54} \mathrm{Bu}$ tarihlerde şeyhülislâm Şeyh Seyyid Mustafa Efendi idi. II. Mustafa'nın hocası ve seyhülislâmı Erzurumlu Seyyid Feyzullah Efendi'nin oğlu olup $1090 / 1679$ 'da doğmuştur. Babasının şeyhülislâmlığ 1 sırasinda süratle yükselerek $1114 / 1702$ senesinde 24 yaşında Anadolu kazaskeri olmus ve hemen arkasından da Rumeli kazaskerliğine yükselmiştir. Edirne vak'ası ve babasının katledilmesi üzerine Mustafa Efendi de, bir müddet Yedikule'de hapsedildikten sonra, Kıbris adasına sürgün edildi ve sonra Bursa'da oturmasına izin verildi. III. Ahmed'in saltanatı müddetince 28 sene Bursa'da kaldı. I. Mahmud hükümdar olunca İstanbul'a getirildi ve 12 Safer 1145 / 16 Ağustos 1733'de Rumeli kazaskerliğine tayin olundu. Dürrî Mehmed Efendi'nin hastalığı dolayısıyla çekilmesi üzerine, 1 Zilhicce 1145 / 15 Mayıs 1733 'de, şeyhülislâm oldu. 9 sene 3 ay bu makamda kaldı. Son zamanlarında felç gelmesine rağmen görevde bırakıldı ve 1158 senesi Muharremi sonunda (1745 Şubat) vefat etti. İ. Hakkı Uzunçarşılı, Osmanlı Tarihi, C.IV-2, Ankara 1988, s.472-473.
} 
dökme meyve (5.600 akçe) ve 8'er tabladan 16 tabla (7.680 akçe) çiçek gönderilmiştir. Tabiî ki, Galata'ya gidecek olan meyve ve çiçekler için 'akkâm ve kayık ücreti de ödenmiştir. 'Akkâm başına 45'er akçeden olmak üzere her elçi için 18 'erden toplam 36 'akkâma 1.620 , her bir kayık için 70 'er akçeden olmak üzere 6'şardan 12 kayık için 840 akçe de bu hesaba dâhil edilecek olursa, her iki elçi için gönderilen meyve ve çiçeğe toplam 15.860 akçe harcanmıştır.

Yine 12 Muharrem 1154 tarihinde Şehzâdebaşı konağ sepet dökme meyve için 1.120 akçe, 2 tabla çiçek için de 960 akçe olmak üzere toplam 2.080 akçe harcandığı görülmektedir.

İlkinden sekiz gün sonra, 20 Muharrem 1154 tarihinde, İran elçisine bir defa daha 40 sepet dökme meyve (2.800 akçe) ile 8 tabla çiçek (3.840 akçe) gönderilmiştir. Bu ürünler için ise yine yukarıda olduğu gibi 18 'akkâm için 45'er akçeden 810 akçe ve ayrıca 6 kayık için de 60'ar akçeden 360 akçe olmak üzere toplam 7.810 akçe masraf yapılmıştır.

Ekstradan ortaya çıkan bir başka harcama kalemi de, 29 Muharrem 1154 tarihinde Şehzâdebaşı'ndaki konağa yapılanıdır. Buna göre, bu konağa meyve ve çiçek yerine konağın bahçesine çeşitli çiçek çanakları alınmıştır. Konağın şehzâde bahçesi için her biri 80'er akçeden 37 adet sadberg gülü dağarı için 2.960 akçe; konağın kapısında olan harem bahçesi için her biri 18 'er akçeden 20 adet şebboy dağarı için 360 akçe, her biri 6'şar akçeden 60 adet hercâi menekşe dağanı ile 40 adet Frenk bâtiyesi dağanı için toplam 600 akçe ki, yekun olarak 4.400 akçe harcanmıştır. Şehzâdebaşı'ndaki konağın bahçesine alınan çiçek çanağı masraflarının da buraya kaydedilmesi ilginçtir.

Yukarıda saydığımız masraflardan ayrı olarak, özel günlerde padişaha ve diğer ileri gelenlere toplu halde alınan meyve ve çiçeklerin masrafları da küçük listeler halinde bu bölümde verilmiştir. Burada üç ayrı günde yapılan harcamalar çok ilgi çekicidir. Bunlar 4 Muharrem, 19 Muharrem ve 23 Muharrem 1154 tarihinde yapılan harcamalardır. 4 Muharrem günü, 21 Mart 1741 'e tesâdüf etmektedir ki, bilindiği gibi 21 Mart, Nevrûz'dur. Bu günde padişahın kendisine, dârüssaâde ağasına ${ }^{55}$, padişahın başkadınına, ikinci, üçüncü, dördüncü ve beşinci kadınlarına meyve ve çiçekler alınarak gönderilmiştir ${ }^{56}$. Ayrıca kendisine meyve ve çiçek gönderilenler arasında

\footnotetext{
${ }^{55}$ Bilindiği gibi dârüssaâde ağası Osmanlı sarayının en büyük görevlilerinden biri olup Enderûn kısmının da sorumlusu idi. Derecesi sadrazam ve şeyhülislâmdan sonra gelirdi. Asıl vazîfesi sarayın kadınlara âit olan harem-i hümâyûn kısmına nezâretti. Kendisi siyah hadım ağalanndan olduğu gibi emri altında haremin hizmetinde kullanılan diğer siyah hadım ağaları vardı. M. Zeki Pakalın, Osmanlı Tarih Deyimleri Ve Terimleri Sözlü̆̆̈̈, C.I, İstanbul 1983, s. 400 .

${ }_{56}$ Hatundan bozma olarak "kadın" unvanı verilenler, padişahın zevceleri sayılırlardı. Bunların adedi dört ve bazen altı ve yedi kadar olurdu; kadınlar kıdem sırasına göre başkadın, ikinci kadın, üçüncü kadın vs. diye anılırlardı; en itibarlıları başkadındı. Kadınların içinden en sevgili olanlara ve çocuk doğuranlara Haseki denirdi. I. Hakkı Uzunçarşılı, Osmanlı
} 
sarayın önde gelen görevlilerinden olan kethüdâ $\operatorname{kad}^{57}{ }^{57}$, hazînedâr usta ${ }^{58}$, hazînedâr-1 şehriyârî lalası, oda lalası, başkapı gulâmı ${ }^{59}$, yazıcı efendi, kethüdâ-y1 teberdârân ${ }^{60}$, dârüssaâde ağası kahvecibaşısı, hazînedâr kahvecibaşısı ve vekîl-i harc-1 teberdârân da bulunmaktadır. İlginç olan husus, Nevrûz günü Osmanlı sarayında bulunan önemli kimselere meyve ve çiçek gönderilmesidir. Günümüzde bazı grupların sâhiplenerek olaylar çıkardıkları Nevrûz günü, Osmanlı sarayında özel günler arasında sayılarak, tebrikleşmeler için çiçekler gönderilmesi, bu günün çok eskiden beri Türkler arasında önemli günlerden addedilerek bayram gibi kutlandığının bir göstergesidir.

İkinci önemli gün ise 19 Muharrem 1154 tarihidir ki, padişahın Topkapı Sarayı'na göç-i hümâyûnlarının olduğu gündür. Yine bu günde de, padişaha ve yukarıda saydı̆̆ımız saray ileri gelenlerine hediye olarak meyve ve çiçek alınmıştır. Topluca meyve ve çiçek alınan bir diğer tarih ise 23 Muharrem 1154 'dür. Ancak, tarihin altında bulunan yazının tahrip olmasından dolayı, padişaha ve bütün saray ileri gelenlerine meyve ve çiçek alınan bu günün ne anlama geldiği anlaşılamamıştır.

Toplu yapılan alımlarda sarayın ileri gelenlerinin statüsüne göre meyve ve çiçek gönderiliyordu. Meselâ padişaha 6 tabla; dârüssaâde ağasına 5; başkadına 3; ikinci, üçüncü, dördüncü ve beşinci kadın ile kethüdâ kadın, hazînedâr usta ve hazînedâr-1 şehriyârî lalasına 2'şer tabla; oda lalası, başkapu gulâmı, yazıcı efendi, kethüdâ-y1 teberdârân, dârüssaâde kahvecibaşısı, hazînedâr kahvecibaşısı ve vekîl-i harc-1 teberdârâna da 1'er tabla çiçek gönderilmiştir. Aynı şekilde alınan meyvelerde de statünün önemli olduğu ortaya çıkmaktadır. Çünkü padişah, dârüssaâde ağası ve başkadına fiyatı daha yüksek olan dökme meyve alınırken, diğerlerine fiyatı daha düşük olan meyve alınmıştır. Dökme meyve sepetinin veya meyve

Devletinin Saray Teşkilâtı, Ankara 1984, s.148.

${ }^{57}$ Kâhya kadın da denilen kethüdâ kadın, sarayda bulunan kızların terbiyesine ve usûle muhalif harekette bulunmamalarına dikkat eder ve öğretirdi. Kâhya kadın, bütün câriyelerin âmiridir; bunun âmirlik alâmeti olarak elinde gümüş kaplı bir deynek ile hünkâr dâiresindeki muhtelif eşyâyı mühürlemek için yanında mühr-i hümâyûn vardır; padişahın kadınları bile ona riayet gösterirlerdi. Uzunçarşılı, Saray Teşkilâtt, s.150.

${ }^{58}$ Kâhya kadının muavinine hazinedâr usta derlerdi. Bu usta, hükümdârın elbiselerine ve harem-i hümâyûn levazımâtına bakar, göçlerde saray kadınlarına refakat ve nezaret ederdi. Uzunçarşıll, Saray Teşkilâtt, s.150. Aynca "hazînedâr kalfa" da denen bu câriyeler padişahı giydirip kuşatmak, yatırıp kaldırmak gibi hususî hizmetle de mükelleftiler. Padişah câriyelerinden istediğini, daha doğrusu hoşlandığını hazînedârlığa tayin ederdi. Sayıları on beşi geçmeyen bu hizmetlilerin ikâmetgâhları da padişahın yatak odasının yakınında olup, geceleri yatak odasının kapısında nöbet beklerlerdi. Pakalın, C.I, s.786.

${ }^{9}$ Başkapu gulâmlı̆̆ı, sarayın önemli görevlilerinden biri olup zenci hadım ağalarına mahsus bir görev idi ve saraya alınan zenci hadım ağalanının defterlerini tutarlardı. Pakalın, C.I, s.165.

6) Teber balta demek olup teberdârân da baltacılar demektir. Padişah sarayının dış hizmetlerinde kullanılan bir kısım hizmetlilerine baltacılar denilmekte idi. Bu ocağın en büyük zâbitine de "kethüdâ-yı teberdârân" denilirdi. Pakalın, C.I, s.154 ; Uzunçarş11, Saray Teşkilâtı, s.435-438. 
sepetinin içinde ne olduğu kaydedilmemişse de, neredeyse iki katına yaklaşan aralarındaki fiyat farkından, dökme meyve sepetinin diğerinden oldukça farklı olduğu ve kaliteli meyvelerden oluştuğu kolayca tahmin edilebilir. Tabiî ki, padişah, dârüssaâde ağası ve başkadına alınan dökme meyve sepetinin sayıları da farklıdır. Padişaha 60 , dârüssaâde ağasına 50 , başkadına da 30 sepet dökme meyve alınmıştır. Yukarıda çiçek alımında gördüğümüz uygulama, burada da aynı şekilde gerçekleştirilmiş ve saray halkına statülerine göre meyve alınmıştır. İkinci, üçüncü, dördüncü, beşinci kadın ile kethüdâ kadın ve hazînedâr ustaya 25 'şer sepet meyve alındığ görülmektedir. Yalnız burada farklı bir uygulamaya tâbi tutulan hazînedâr-1 şehriyârî lalasıdır ki, kendisine 20 sepet dökme meyve alınmıştır. Bu farklı uygulamanın sebebi anlaşılamamıştır. Oda lalası, başkapu gulâmı, yazıcı efendi, kethüdâ-yı teberdârân, dârüssaâde kahvecibaş1sı, hazînedâr kahvecibaşısı ve vekil-i harc-1 teberdârâna da 10'ar sepet meyve alındığı görülmektedir. Böylece sarayın ileri gelenlerine bu üç özel günde toplam 35 'er tabla çiçek, 220 'şer sepet meyve ve 160'ar sepet de dökme meyve alındığı görülmektedir.

Buna göre 1154 senesi Muharremi içerisinde, Osmanlı padişahının sarayına, günlük harcamaların dışında, zuhûrâta bağlı olarak ekstradan 708 sepet dökme meyve (49.560 akçe), 660 sepet meyve-i mütenevvi'a (29.700 akçe) ve 142 tabla da çiçek (68.160 akçe) girmiştir. Bu ürünlerin taşınması için 'akkâm, hammâliye ve kayık masrafı olarak da 6.225 akçe harcanmıştır. Yapılan diğer harcamalarla birlikte sarayın bu ayki ekstra meyve ve çiçek masrafı 162.590 akçeyi, yâni 1.354,5 guruşu bulmuştur. Sarayın günlük mutâd ve olağanüstü durumlarda alınan meyve ve çiçek masrafının toplamı ise 249.065 akçe olup bu da 2.075 guruş etmiştir. Bunun 75 guruşu tenzîl edilmiş ve geriye kalan 2.000 guruşunun hazîneden ödenmesi için hazînedâr ağaya gereken talimât verilmiştir.

Listenin sonunda ise 1154 senesi Muharrem ayının yevmiye mutâd meyve ve çiçek masrafı ile zuhûrậta bağlı olarak ortaya çıkan masrafları guruş olarak verildikten sonra, ne kadarının tenzîl edildiği ve ne kadarının da hazîneden ödenmesi gerektiği, ayrıca bunun padişahın onayından geçtiği, hazînedâra yazılan bir yazı ile bildirilmiştir.

Birinci listeye oranla çok daha muhtasar olan ikinci liste ise 1158 senesi Ramazânına âit (27 Eylül-26 Ekim 1745) sarayın bir aylık meyve ve çiçek masraflarını içermektedir. Listeye kaydedilen harcamalar, birinci belgede olduğu gibi, günlük mutâd harcamalar ve ay içinde zuhûrâta bağlı olarak ortaya çıkan masraflar şeklinde iki başlık halinde değerlendirmeye tâbi tutulacaktır.

1 Ramazân Pazartesi günü başlayıp 30 Ramazân Salı günü sona eren listede saray için günlük mutâd alınan meyve ve çiçeğin miktar ve fiyatının, 
birinci listeden neredeyse dört buçuk yıl sonraya âit olmasına rağmen, değișmediği görülmektedir. Buna göre saraya yine her gün 51 sepet meyve ve Pazartesi ile Cuma günleri olmak üzere haftada iki gün 3'er tabla çiçek alınmıștır. Bu ay içinde saraya alınan meyve miktarı 1530 sepet olup sepeti 45'er akçeden 68.850 akçe; çiçek miktarı 27 tabla olup tablas 180 akçeden 12.960 akçe; hammâliye olarak da 409 kişiye 15 'er akçeden 6.135 akçe olmak üzere toplam 87.945 akçe ödenmiş, bu da 733 guruş 15 akçe etmiştir.

1158 senesi Ramazân ayı ile 1154 senesi Muharrem ayında yapılan günlük mutâd harcamalar karşılaştırıldığında çok fazla bir farklılık arz etmediği görülür. Her iki ayda da meyve için harcanan paranın aynı olduğ̆u, çiçek için harcanan paranın ise yalnızca 1.470 akçe fark ettiği görülecektir. Bunun da, 1158 senesi Ramazânında fazladan alınan 3 tabla çiçek ve 2 adet işçi ücretinden kaynaklandığı ortaya çıkmaktadır.

1158 senesi Ramazânında zuhûrâta bağlı olarak ortaya çıkan harcamalara gelince:

Burada verilen masraf kalemleri 3 ayrı günde yapılan harcamaları ihtiva etmektedir. Birincisi 5 Ramazân gününe âit olup padişahın Ağa Câmii'ne vardığ 1 gün telhîsci ağa marifetiyle saraya gönderilen meyve ve çiçekleri içermektedir. Burada padișaha 80 sepet dökme meyve ve 8 tabla çiçek; dârüssaâde ağasına 50 sepet dökme meyve ve 5 tabla çiçek; hazînedâra da 20 sepet dökme meyve ile 2 tabla çiçek gönderildiği kaydedilmiștir.

Zuhûrâta bağlı olarak ortaya çıkan ikinci harcama kalemi ise 12 Ramazân 1158 (8 Ekim 1745) tarihine âittir. Bu gün yapılan harcamaların sebebinin ise, göç-i hümâyûnun Topkapusundan saray-1 hümâyûna gelmesi olarak ifâde edilmiştir. Birinci belgede padişahın 19 Muharrem 1154 (6 Nisan 1741) günü Topkapusuna göçtükleri ifâde edilmiş ve sarayın ileri gelenlerine meyve ve çiçekler gönderildiği daha önce gösterilmişti. Öyle anlaşılıyor ki, padişah bahar mevsimi geldiğinde Topkapı Sarayı'na, güz gelince de saray-1 hümâyûna göçmektedir ${ }^{61}$. Her iki göç esnasında sarayın ileri gelen görevlileri ile padişahın kadınlarına meyve ve çiçekler gönderilmiştir.

Toplu yapılan alımlarda kimlere ne kadar meyve ve çiçek gönderildiği birinci belgede verilenlerle aynı olduğu için burada tekrarlamaya lüzum görülmemiştir. Ancak yalnızca padişaha alınanlarda birinci listede verilenlerden farklı olarak 2 tabla çiçek ve 20 sepet dökme meyvenin fazla alındığ 1 görülmektedir. Burada toplam olarak 37 tabla çiçek, 220 sepet meyve ve 180 sepet de dökme meyve alınmıştır.

\footnotetext{
${ }^{61}$ Burada "saray-1 hümâyûn" ile kastedilen yerin neresi olduğu açık değildir. Ancak, 17. ve 18. yüzyıllarda padişahların genellikle Edirne'de oturmalanından dolayı, bu sarayın Edirne Sarayı olma ihtimalinin yanında, İstanbul'daki Eski Saray olma ihtimali de vardır.
} 
İkinci listenin zuhûrâta bağlı olarak ortaya çıkan harcamalarının kaydedildiği bölümde ilginç olan hususlardan biri de 30 Ramazân 1158 tarihini taşıyan harcama kalemidir ki, bu gün, arîfe günüdür. Kayıtta bulunan "bâ-fermân-1 'âlî arîfe günü sultân-1 "âlîşân hazerâtına" ifâdesiyle, padişah emriyle saraya mensup sultanlara bayram hediyesi olarak meyve ve çiçek alınarak gönderildiği anlaşılmaktadır. Bilindiği gibi "Sultan" tabiri padişah kızlarına verilen bir unvandır. Bu itibarla kendilerine meyve ve çiçek alınarak gönderilen bu sultanların padişahın kızları olmaları icâb eder. 1158 / 1745 tarihinde tahtta bulunan padișah Sultan I. Mahmud'dur. Ancak bu padişahın hiç çocuğu olmadığı için, kendilerine çiçek ve meyve gönderilen sultanların padişah I. Mahmud'un kız kardeşleri ve amcası Sultan III. Ahmed'in kızları olduğu anlaşılmaktadır ${ }^{62}$.

$\begin{array}{cll}\text { Kendilerine } & \text { arîfe günü bayram hediyesi } & \text { olarak } \\ \text { meyve ve çiçek } & \text { gönderilen sultanlar arasında Ayşe Sultan }{ }^{63} \text {, } \\ \text { Sâfiye Sultan }{ }^{64} \text {, Zeyneb Sultan } & \text { Z5, Küçük Ayşe Sultan }{ }^{66} \text {, Sâliha }\end{array}$

${ }^{62}$ M. Çağatay Uluçay, Padişahların Kadınları ve Kızları, Ankara 1985, s.73-96; Ahmet Akgündüz, Osmanll'da Harem, İstanbul 1995, s.334-335.

${ }_{63}$ Aynı dönemde yaşayan III. Ahmed'in kızı Ayşe Sultan'dan ayırt etmek için Büyük lakabıyla anılan Ayşe Sultan, II. Mustafa'nın kızı olup 30 Nisan 1696'da doğmuş̧tur. 1703'de yedi yaşında Köprülü zâde Numan Paşa ile nişanlanmalarına rağmen, ancak, Paşa'nın Bosna valiliği sırasında, 1708 'de evlenebilmişlerdir. Numan Paşa iki sene sonra vezir-i a'zâm oldu. Aynı sene içerisinde azl olunarak değişik görevlerde bulundu ise de 1719 yılında Girit valisi iken 50 yaşlarında öldü. Dul kalan Ayşe Sultan bir sene sonra Tezkireci İbrahim Paşa ile, onun da 1722 y1lında ölmesi üzerine, Koca Mustafa Paşa ile evlendi (1725). Mustafa Paşa'nın da 1728 yılında ölümü ile bir daha evlenmedi ve 1752 'de vefat edip Yeni Cami Türbesine defnedildi. Uluçay, s.75-76.

${ }^{64}$ Sâfiye Sultan, II. Mustafa'nın kızlarından olup 1696'da doğdu. Yedi yaşında iken Merzifonlu Kara Mustafa Paşa'nın oğlu Ali Paşa ile, 1703'de nişanlanmalarına rağmen, düğünleri ancak $1710^{\prime}$ da yapılabildi. Safiye Sultan evlendiği zaman 14 yaşında bulunuyordu ve Ali Paşa ile 13 yıl mesut bir hayat sürdü. Ali Paşa'nın 1723'de ölümü üzerine dul kald1. 1726'da Mirza zâde Mehmed Paşa ile evlendi. İki sene sonra Mehmed Paşa da öldü. Sâfiye Sultan üçüncü defa 1740 yılında Alâiyeli Ebubekir Paşa ile evlendi. 1759 yılında Ebubekir Paşa'nın ölmesi üzerine yine dul kalan Sâfiye Sultan, bu sırada 63 yaşında idi ve 1778 yılında, 82 yaşında ölümüne kadar, bir daha evlenmedi. Kanûnî Sultan Süleyman Türbesi'nin dişında gömülüdür. Sâfiye Sultan ömrü boyunca pek çok vakıf ve hayır eserleri yaptırmıştır. Uluçay, s. $77-78$

${ }^{65}$ Sultan III. Ahmed'in kızlarından olan Zeyneb Sultan'ın doğum tarihi belli değildir. Düğünü 1728 yılında kardeşleri Ayşe ve Saliha Sultanlarınki ile birlikte yapılmıştır. Zeyneb Sultan Sinek ve Küçük lakablarıyla anılan Mustafa Paşa ile evlendi. Evlilik hayatı, Sinek Mustafa Paşa'nın 1764 yılında ölümüne kadar devam etti. Mustafa Paşa ölünce bir yıl kadar dul kaldı. $1765^{\prime}$ de eski derya kaptanlarından Melek Mehmed Paşa ile evlendi. Zeyneb Sultan 12 Muharrem 1188 (25 Mart 1774) tarihinde öldü. 1769 Yılında Alemdar'daki "Ruh-i Sultaniye" Camiini, mektebini ve sebilini yaptırmıştır. Bugün Zeyneb Sultan Camii olarak anılan bu camiin bahçesinde yatmaktadır. Uluçay, s.86-87.

${ }^{\infty}$ Küçük Ayşe Sultan, III. Ahmed'in kızlarındandır. Doğum tarihi hususunda ihtilaf varsa da 1715 olarak kabul edilir. Sultan Ahmed, 1728 yılında, 12-13 yaşlarında evlendirdiği üç kızının düğününü birlikte yapmıştır. Ayşe Sultan'1 da 13 yaşında, Istanbullu Mehmed Paşa ile evlendirdi. Ayşe Sultan, Mehmed Paşa'nın 1737'de ölmesi üzerine dul kaldı. 1740'da vezir-i a'zâm Topal Osman Paşa'nın oğlu Ratip Ahmed Paşa ile ikinci defa evlendi. Ratip Paşa'nın da 1758 'de ölümü üzerine ikinci defa dul kaldı. 1758'de kardeşi III. Mustafa tarafından Tırhala Sancakbeyi Silahdâr Mehmed Paşa ile yeniden evlendirildi. 1775'de de vefat etti ve 
Sultan ${ }^{67}$ ve Esmâ Sultan' ${ }^{68}$ isimleri sayılmaktadır. Ayşe Sultan (Büyük) ile Sâfiye Sultan padişahın kız kardeşleri, diğer dört sultan ise amcası III. Ahmed'in kızlarıdır. Arîfe günü kendilerine çiçek gönderilen bu sultanların bizzat sarayda oturmadıkları, çünkü çoğunun bu tarihte önemli devlet adamları ile evli oldukları görülmektedir. Yalnız III. Ahmed'in kızı olan Sâfiye Sultan'ın, bu tarihlerde dul olduğu için, sarayda oturma ihtimali vardır. Bu itibarla alınan meyve ve çiçeklerin saray dışına bu sultanların kendi konaklarına gönderildiği tahmin edilmektedir.

Bu sultanların her birine 48 'er sepet dökme meyve ve 4'er tabla da çiçek gönderilmiştir. Toplam olarak 288 sepet dökme meyve ve 24 tabla da çiçek alınmış olup bunlardan 80 sepet meyve ile 8 tabla çiçeğin masrafı yeniçeri ağası tarafından, 80 sepet meyve ile 8 tabla çiçeğin masrafı da Gümrük Emîni İshâk Ağa tarafından karşılanmıştır. Geri kalan 128 sepet meyve ile 8 tabla çiçeğin masrafı ise hazîneden ödenmiştir.

Arîfe günü kendisine meyve ve çiçek gönderilen bir başka kişi de şeyhülislâmdır. Bu sırada şeyhülislâm Pirîzâde lakabıyla tanınan Mehmed Sâhib Efendi idii ${ }^{69}$. Şeyhülislâmın konağına 40 sepet dökme meyve (2.800

Yeni Cami haziresine gömüldü. III. Ahmed kızı Ayşe Sultan'a Rami Paşa Sarayı'nı ve Bahariye yalısını temlik etmiştir. Ayşe Sultan Bahariye yalısı yanındaki arsaları, Ankara ve İzmit'teki bazı emlakini vakfetmiş ise de nerelere vakfettiği bilinmiyor. Uluçay, s.88.

${ }^{67}$ Sâliha Sultan, III. Ahmed'in kızlarından olup 1715 yılında doğdu. 1728 yılında Deli Hüseyin Paşa'nın oğlu Sarı Mustafa Paşa ile evlendi. Sarı Mustafa Paşa'nın 1731'de ölmesi üzerine dul kaldı. 1740'da I. Mahmud tarafından Abdi Paşa zâde Ali Paşa ile evlendirildi. Sâliha Sultan'in bu evliliği de kısa sürdü. Ali Paşa 1744'de ölünce, ikinci defa dul kaldı. Bu seferki bekarlığı 14 sene sürdü. Nihayet kardeşi III. Mustafa hükümdar olunca, dul kalan diğer kardeşlerini evlendirdiği sırada, 1758'de Sâliha Sultan'ı da Ragıp Paşa ile evlendirdi. Sâliha Sultan, Ragıp Paşa'nın üçüncü eşi idi. Ragıp Paşa 61, Sâliha Sultan 44-45 yaşlarında idi. Sadrazam Ragıp Paşa'nın 1763'de ölmesi üzerine üçüncü defa dul kaldı. III. Mustafa'nın arzusu üzerine 1764'de eski yeniçeri ağalarından ve kaptan-1 deryalardan Mehmed Paşa ile evlendi. 1770'de Mehmed Paşa'nın da ölümü üzerine bir daha evlenmedi ve 1778 yılında öldü. Eyüb Sultan Türbesi kapısına gömülmüş̧ür. Uluçay, 90.

${ }_{68}^{68}$ Esma Sultan III. Ahmed'in kızlarından olup 1726 yılında doğdu. I. Mahmud tarafından 1743 'de Yakup Paşa ile evlendirildi. Fakat Yakup Paşa'nın bir sene sonra ölmesi üzerine I. Mahmud tarafından bir başkasıyla evlendirildiyse de ismi bilinmiyor. Nihayet III. Mustafa diğer dul kardeşlerini evlendirdiği gibi Esma Sultan'ı da Muhsin zâde Mehmed Paşa ile 1758'de evlendirmiştir. Kocası Mehmed Paşa iki defa sadrazam oldu. İki kardeşinin padişahlıkları sırasında çok önemli mal ve mülke sâhip olup İstanbul'un sayılı zengin kadınları arasına girdi. Muhsin zâde Mehmed Paşa 1774'de ölünce de bir daha evlenmedi. 1788 yılında öldü ve Eyüp'teki Muhsin zâde Mehmed Paşa Türbesi'ne gömüldü. Uluçay, s.90-91.

${ }^{69}$ Pirîzâde Mehmed Sâhib Efendi 1085 / 1674'de doğmuş olup babası yeniçeri ocağından yetişmiş Pirî adında biri olduğundan bu aileden yetişmiş olanlara Pirîzâde denilmiştir. Evvelâ Şeyhülislâm Erzurumlu Seyyid Feyzullah Efendi'ye intisâb etmiş, sonra da onun emriyle önce vezir-i azam Daltaban Mustafa Paşa'ya, arkasından da Ramî Mehmed Paşa'ya imam oldu. $1113 / 1701$ 'den itibaren de çeşitli kademelerde müderrislik etti. $1135 / 1723$ 'de Selanik kadılığına tayin edildi; 1140 / 1727 'de padişahın ikinci imamı ve şehzadelerin muallimi oldu. Daha sonra birinci imamlığ 1 yükselerek 1143 / 1731'de İstanbul kadısı olup aynı zamanda Anadolu kazaskeri payesi verildi. 1150/1737'de Rumeli kazaskerliğine tayin edildi. Şeyhülislâm Şeyh Mustafa Efendi'nin vefatı ile I. Mahmud tarafından Muharrem 1158 / Şubat 
akçe) ve 5 tabla da çiçek (2.400 akçe) gönderilmiştir. Şeyhülislâm için harcanan meblağ ise 5.200 akçe olmuştur.

1158 senesi Ramazân ayının ekstra meyve ve çiçek harcamalarının toplamı 498 sepet dökme meyve (34.860 akçe), 220 sepet meyve ( 9.900 akçe) ve 65 tabla çiçektir (31.200 akçe). Bunlara hammâliye olarak da 7.350 akçe ödenmiştir. Böylece bu ayın zuhûrâta bağlı meyve ve çiçek masrafı 83.310 akçe olmuştur. Ayın hem günlük mutâd masrafı hem de ekstradan ortaya çıkan masraflarının toplamı ise 171.255 akçeyi bulmuş, bu da $1.427,5$ guruş etmiştir. Toplam masraf olan bu miktardan 7,5 guruşunun tenzil edilerek 1158 senesi Ramazânının meyve ve çiçek masrafının 1.420 guruş olduğu kaydedilmiştir.

Belgenin sonunda Selh-i Ramazân 1158 (26 Ekim 1745) günü hazînedâr ağaya yazılan bir not ile 1.420 guruşun yemişcibaşıya verilmesi istenmiştir. Buradan da saray için yapılan bütün bu harcamaların yemişcibaşı eliyle yapıldığ Ağa'nın notu bulunmaktadır. Bu notta 18 Zilkade 1158 (12 Aralık 1745) tarihinde, 1158 senesi Ramazânına âit meyve ve çiçek masrafı olan 1.420 guruşun hazînedâr ağa elinden tamamen alındığı ifâde edilmiştir.

\section{Sonuç}

16. yüzyıl ile 19. yüzyıl arasında Osmanlı Devleti'nde tüketilen meyve türleri çok fazla bir değişiklik göstermemiştir. Buna bağlı olarak Osmanlı sarayında tüketilen meyvelerde de bir değişiklik olmamıştır. Sarayın ihtiyacı olan meyveler genellikle İstanbul çevresinden ve yakın yerlerden temin edilmiştir. Aynı şekilde sarayda meyvelerin yanı sıra belli miktarda çiçek tüketildiği de görülmektedir. Sarayda tüketilen bu çiçeklerin yalnızca tatlı ve reçel yapımında kullanılmadığı aynı zamanda padişaha ve saray görevlilerine de hediye edildiği ortaya çıkmaktadır.

18. yüzyılın ortalarında Osmanlı sarayına her gün mutâd olarak 51 sepet meyve ve haftanın belirli günleri, meselâ Pazartesi ile Cuma günleri, 3'er tabla da çiçek alınıyordu. Ayrıca bazı özel günlerde ve bayramlarda padişaha, dârüssaâde ağasına, şeyhülislâma, padişahın kadınlarına ve kızlarına da meyve ve çiçek alınarak gönderiliyordu. Bunların yanında yine sarayda bulunan kethüdâ kadın, hazînedâr usta, hazînedâr-1 şehriyârî lalası, oda lalası, başkapı gulâmı, yazıcı efendi, baltacılar kethüdâsı, dârüssaâde ağası kahvecibaşısı, hazînedâr kahvecibaşısı ve baltacılar kethüdâsı vekiline de meyve ve çiçekler alınarak gönderildiği ortaya çıkmaktadır. Bunlardan

1745'de şeyhülislâmlığa getirildi. Mehmed Sâhib Efendi'nin şeyhülislâmlığı on üç buçuk ay devam etmiş, ancak hastalığı sebebi ile 5 Nisan 1746'da azledilerek yerine Rumeli kazaskeri Hayatî Mehmed Efendi getirilmiștir. Sâhib Mehmed Efendi 9 Receb 1162 / 25 Haziran 1749'da yaşı sekseni geçtiği halde vefat etmiştir. Âlim ve yüksek mütefekkir bir zat idi. Uzunçarşıll, Osmanlı Tarihi, C.IV-2, s.473-474. 
başka çeşitli devletlerin elçilerine İstanbul'a geldiklerinde ve burada bulundukları süre içerisinde meyve ve çiçek hediye ediliyordu. Bütün bunlar Osmanlı sultanlarının ve diğer devlet adamlarının yalnızca savaştan savaşa koşan adamlar olmayıp aynı zamanda birbirilerine çiçekler hediye edecek kadar ince bir ruha sâhip kimseler olduklarını ortaya koymaktadır.

\section{KAYNAKÇA}

\section{I-Arşiv Belgeleri}

Başbakanlık Osmanlı Arşivi, Cevdet Saray, no. 2608.

Başbakanlık Osmanlı Arşivi, Cevdet Saray, no. 2354.

Başbakanlık Osmanlı Arşivi, Mühimme Defteri, C.69, Sıra no: 177, s.89.

\section{II- Araştırma ve İncelemeler}

AKGÜNDÜZ, Ahmet, Osmanli'da Harem, İstanbul 1995.

ALTINAY, Ahmed Refik, Onuncu Asr-ı Hicrîde İstanbul Hayatı, (Haz: Abdullah Uysal), Ankara 1987.

BARKAN, Ömer Lütfi, "İstanbul Sarayına Ait Muhasebe Defterleri", Belgeler, C.IX, S.13, Ankara 1979, s.1-380.

BİLGIN, Arif, Osmanlı Sarayının İạsesi (1489-1650), Marmara Üniversitesi Sosyal Bilimler Enstitüsü, (Basılmamış Doktora Tezi), İstanbul 2000.

EMECEN, Feridun M., "Şehzadenin Mutfağı: III. Mehmed'in Şehzadelik Döneminde Manisa Sarayına Ait Bir Mutfak Masraf Defteri", Soframız Nur Hânemiz Mamur Osmanlı Maddi Kültürü̈nde Yemek Ve Barınak, (Editörler: Suraiya Faroqhi- Christoph K. Neumann), İstanbul 2006, s.111-147.

MANTRAN, Robert, 17. Yüzyılln Ikinci Yarısında İstanbul, C.I, (Çev: Mehmet Ali Kılıçbay, Enver Özcan), Ankara 1990.

ORTAYLI, İlber, Osmanlı'yı Yeniden Keşetmek, İstanbul 2006.

PAKALIN, M. Zeki, Osmanl Tarih Deyimleri Ve Terimleri Sözlüğ̈̈, C.I, İstanbul 1983.

POLAT, N. Hikmet, Türk Çiçek Ve Ziraat Kültürü Üzerine, Cevat Rüştü'den Bir Güldeste, İstanbul 2001.

REINDL-KIEL, Hadde, "Cennet Taamları, 17. Yüzyıl Ortalarında Osmanlı Sarayında Resmi Ziyafetler", Soframız Nur Hânemiz Mamur Osmanlı Maddi Kültüründe Yemek Ve Barınak, (Editörler: Suraiya Faroqhi- Christoph $\mathrm{K}$. Neumann), İstanbul 2006, s.55-109. 
SAMANCI, Özge, "19. Yüzyllın İkinci Yarısında Osmanlı Elitinin Yeme-İçme Alışkanlıkları", Soframız Nur Hânemiz Mamur Osmanlı Maddi Kültürü̈nde Yemek Ve Barınak, (Editörler: Suraiya Faroqhi- Christoph K. Neumann), İstanbul 2006, s.185-207.

TAVERNIER, J. B., Bir Fransız Seyyahın Gözüyle Topkapı Sarayı'nda Yaşam, Büyük Senyörün Sarayı, (Çev: Haluk Yanardağ), İstanbul 2005.

TÜRK DİL KURUMU, Tarama Sözlü̆̈̈̈, C.II, Ankara 1965.

ULUÇAY, M. Çağatay, Padişahların Kadınları ve Kızları, Ankara 1985.

UZUNÇARŞILI, İ. Hakkı, Osmanlı Devletinin Saray Teşkilâtı, Ankara 1984.

UZUNÇARŞILI, İ. Hakkı, Osmanlı Tarihi, C.IV-2, Ankara 1988. 


\section{EK : 1}

\section{Cevdet Saray, no. 2608}

Mâh-1 Muharrem gurresinden devletlü 'inâyetlü veliyyü'n-ni'am kesîrü'l-kerem efendimiz hazretlerinin taraf-1 'âlîlerinden be-her yevm şevketlü 'azametlü hünkârımıza ve dâire-i hümâyûnlarına virilen elli bir sepet meyve ve haftada iki gün Cum'a ve Pazarertesi virilen üçer tabla şükûfe ${ }^{70}$ beyân olunur sene 1154 Eyyâm 30 (19 Mart-17 Nisan 1741).

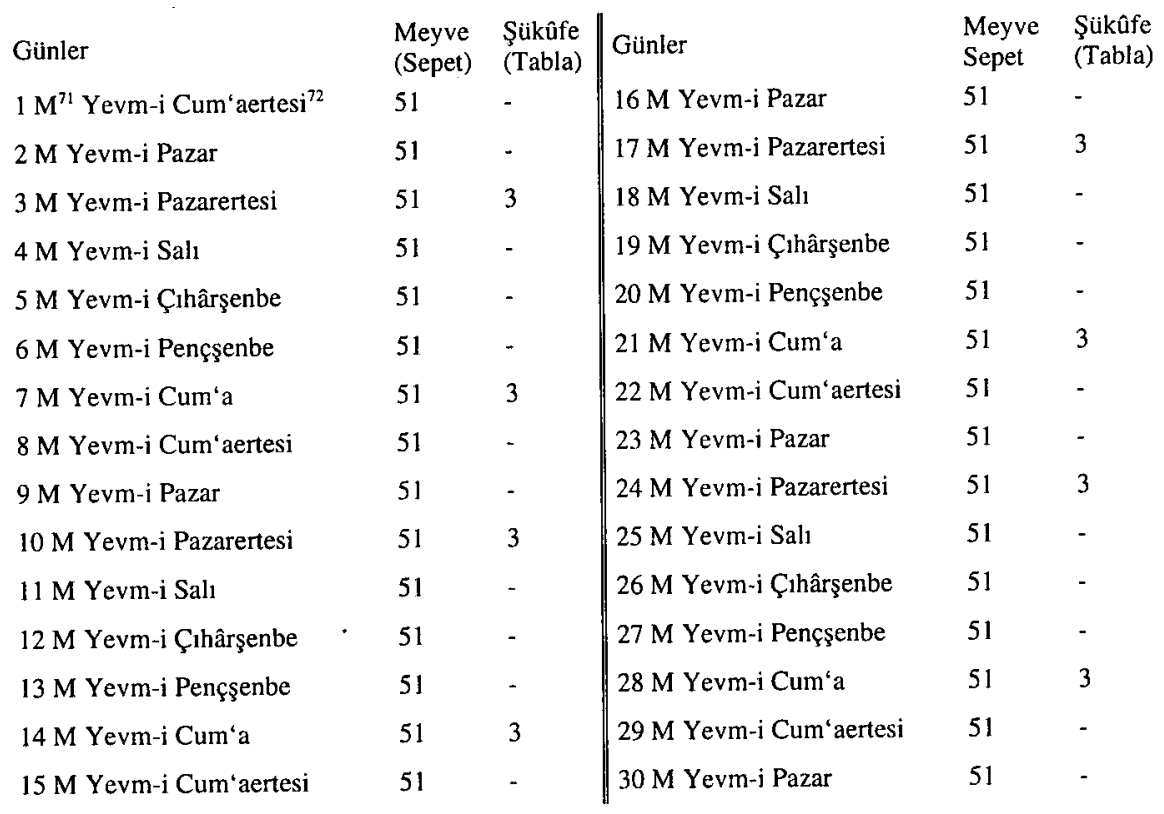

Yekûn Eyyâm 30

Meyve sepet

1.530, fî 45

68.850

Şükûfe tabla

24 , fî 480

11.520

Hammâliye

407 , fî 15

6.105

Yekûn

$\begin{array}{ll}\text { Akçe } & 86.475 \\ \text { Gurus } & 720,5\end{array}$

\footnotetext{
${ }^{70}$ Şükûfe : Çiçek

${ }^{71} \mathrm{M}$ : Muharrem

72 Tüm tarih çevirme kılavuzlarında 1 Muharrem 1154 tarihi Pazar günü olarak verilmesine rağmen burada Cumartesi olarak verilmiştir. Bunun neden kaynaklandığ bilinmemekle birlikte listenin sonradan düzenlendiği ve kâtip tarafından günün sehven Cumartesi olarak kaydedildiği tahmin edilmektedir.
} 
Berây-I zuhûrât şehr-I minhu

Gurre-i M sene 1154 (19 Mart 1741)

Berây-1

Bâ-ma'rifet-i hazînedâr ağa Mehter Mehmed yediyle

Dökme meyve sepet

Şükûfe tabla

\section{M sene 1154 (20 Mart 1741)}

Berây-I

Fazîletlü Şeyhü'l-islâm Efendi hazretlerine sa'âdetlü re'is efendi ma'rifetiyle

Dökme meyve sepet 40

Şưûfe tabla

5

\section{Fî 4 M sene 1154 (22 Mart 1741)}

Berây-1

Bâ-fermân-1 hazret-i veliyyü'n-ni'am Nevrûz günü şevketlü 'azametlü hünkârımıza ve dâire-i harem-i hümâyûna telhîsci ağa ma'rifetiyle umûm.

\begin{tabular}{|c|c|c|c|}
\hline & $\begin{array}{l}\text { Sükûfe } \\
\text { (Tabla) }\end{array}$ & $\begin{array}{l}\text { Meyve } \\
\text { (Sepet) }\end{array}$ & $\begin{array}{l}\text { Dökme } \\
\text { Meyve } \\
\text { (Sepet) }\end{array}$ \\
\hline Şevketlü ‘Azametlü Hünkârımıza & 6 & -- & 60 \\
\hline Devletlü Dârü’s-sa‘âde Ağasına & 5 & - & 50 \\
\hline İsmetlü Baş Kadına & 3 & -- & 30 \\
\hline İsmetlü İkinci Kadına & 2 & 25 & -- \\
\hline İsmetlü Üçüncü Kadına & 2 & 25 & -. \\
\hline İsmetlü Dördüncü Kadına & 2 & 25 & - \\
\hline Yekûn & 20 & 75 & 140 \\
\hline İsmetlü Beşinci Kadına & 2 & 25 & -- \\
\hline İsmetlü Kethïdâ Kadına & 2 & 25 & -- \\
\hline İsmetluj Hazînedâr Ustaya & 2 & 25 & --- \\
\hline Sa‘âdetlü Hazînedâr-ı Şehriyârî Lalaya & 2 & -- & 20 \\
\hline Yekûn & 28 & 150 & 160 \\
\hline Oda Lalasina & 1 & 10 & $\cdots$ \\
\hline
\end{tabular}


Başkapu Gulâmı

Yazıcı Efendi

Kethüdâ-i Teberdârân

Kahvecibaşı-yı Dâriu’s-sa'âde

Hazînedâr Kahvecibaşısına

Vekîl-i harc-1 Teberdârân

Yekûn
$1 \quad 10$

110

110

10

110

110

35

220

\section{M sene 1154 (23 Mart 1741)}

Berây-1

Sa'âdetlü kethüdâ beg emriyle yeni Françe elçisi geldikde Galata'ya gönderilen

$\begin{array}{lcc}\text { Dökme meyve sepet } & 40 \\ \text { Şükûfe tabla } & & 5 \\ \text { 'Akkam'3 } & \text { fị } 45 & 15 \\ \text { Kayık } & \text { fí } 60 & 6\end{array}$

\section{M sene 1154 (30 Mart 1741)}

Berây-1

İran elçisine Kapucubaşı Ya'kûb Ağa yediyle el-yevmiye

Dökme meyve sepet

40

Şükûfe tabla

8

'Akkâm el-yevmiye

fî 45

18

Kayık

fî 60

73 'Akkam : Deveci, Katırci. 
Fî 12 M sene 1154 (30 Mart 1741)

Berây-1

Moskov elçisi Galata'ya geldiği günün ertesi gönderilen

Dökme meyve sepet

40

Şükûfe tabla

8

'Akkâm

fi 45

18

Kayık

fî 60

6

Fî 12 M sene 1154 (30 Mart 1741)

Berây-1

Bâ-fermân-1 'âlî mehterbaşı ma'rifetiyle Mehter Abdullah yediyle Şehzâdebaşı konağına

Dökme meyve sepet

Şükûfe tabla

\section{Fî 19 M sene 1154 (6 Nisan 1741)}

Berây-1

Bâ-fermân-ı 'âlî şevketlü 'azametlü hünkârımız Topkapusuna göç-i hümâyunları oldukda telhîsci ağa ma' rifetiyle

\begin{tabular}{|c|c|c|c|}
\hline & $\begin{array}{l}\text { Şükûfe } \\
\text { (Tabla) }\end{array}$ & $\begin{array}{l}\text { Meyve } \\
\text { (Sepet) }\end{array}$ & $\begin{array}{l}\text { Dökme } \\
\text { Meyve } \\
\text { (Sepet) }\end{array}$ \\
\hline Şevketlü ‘Azametlü Hünkârımıza & 6 & -- & 60 \\
\hline Devletlü Dâriu's-sa'âde Ağasına & 5 & -- & 50 \\
\hline İsmetlii Baş Kadına & 3 & -- & 30 \\
\hline İsmetlü İkinci Kadına & 2 & 25 & -- \\
\hline İsmetlü Üçüncủ Kadına & 2 & 25 & -- \\
\hline İsmetlü Dördüncü Kadına & 2 & 25 & - \\
\hline Yekûn & 20 & 75 & 140 \\
\hline İsmetlü Beşinci Kadın & 2 & 25 & --- \\
\hline İsmetlü Kethüdâ Kadın & 2 & 25 & --- \\
\hline İsmetlü Hazinedâr Usta & 2 & 25 & --- \\
\hline Sa'âdetlü Hazînedâr-1 Şehriyârî Lalaya & 2 & -- & 20 \\
\hline
\end{tabular}


Oda Lalasına

Yekûn

Başkapu Gulâmına

Yazıcı Efendi

Kethuidâ-i Teberdârân

Ser-Kahve-i Dârü's-sâ‘âde Ağası

Ser- Kahve-i Hazînedâr-1 Şehriyârî

Vekîl-i harc-1 Teberdârân

Yekûn

$\begin{array}{lll}1 & 10 & --- \\ 29 & 160 & 160 \\ 1 & 10 & -- \\ 1 & 10 & -- \\ 1 & 10 & -- \\ 1 & 10 & -- \\ 1 & 10 & -- \\ 1 & 10 & -- \\ 35 & 220 & 160\end{array}$

Fî $23 \mathrm{M}$ sene 1154 (10 Nisan 1741)

Berây-1 Bâ-fermân-1 'âlî ..(tahrîb olmuş okunmuyor).. oldukda umûma telhîsci ağa ma'rifetiyle

\begin{tabular}{|c|c|c|c|}
\hline & $\begin{array}{l}\text { Şükûfe } \\
\text { (Tabla) }\end{array}$ & $\begin{array}{l}\text { Meyve } \\
\text { (Sepet) }\end{array}$ & $\begin{array}{l}\text { Dökme } \\
\text { Meyve } \\
\text { (Sepet) }\end{array}$ \\
\hline Şevketlü 'Azametlü Hünkârımıza & 6 & -- & 60 \\
\hline Devletlü Dârü's-sa'âde Ağasına & 5 & -- & 50 \\
\hline İsmetlü Baş Kadına & 3 & -- & 30 \\
\hline İsmetlü İkinci Kadın & 2 & 25 & -- \\
\hline İsmetlü Üçüncü Kadın & 2 & 25 & -- \\
\hline İsmetlü Dördüncü Kad̉n & 2 & 25 & -- \\
\hline Yekûn & 20 & 75 & 140 \\
\hline İsmetlü Beşinci Kadın & 2 & 25 & --- \\
\hline İsmetlü Kethüdâ Kadın & 2 & 25 & $\cdots$ \\
\hline İsmetlü Hazinedâr Usta & 2 & 25 & -- \\
\hline Sa'âdetlü Hazînedâr-ı Şehriyârî Lalasına & 2 & -- & 20 \\
\hline Oda Lalasına & 1 & 10 & $\cdots$ \\
\hline Yekûn & 29 & 160 & 160 \\
\hline Başkapu Gulâmına & 1 & 10 & --- \\
\hline Yazıcı Efendi & 1 & 10 & 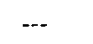 \\
\hline
\end{tabular}


Kethüdâ-i Teberdârân

Ser-Kahve-i Dârü's-sâ‘âde Ağası

Ser-Kahve-i Hazînedâr-1 Şehriyârî

Vekîl-i harc-ı Teberdârân

Yekûn

$\begin{array}{lll}1 & 10 & \cdots \\ 1 & 10 & \cdots \\ 1 & 10 & \cdots \\ 1 & 10 & \cdots \\ 35 & 220 & 160\end{array}$

\section{Fî 20 M sene 1154 (7 Nisan 1741)}

Berây-1

...(tahrî̀b olmuş okunmuyor)... İran elçisine el-yevmiye Münîf Efendi yediyle

Dökme meyve sepet

40

Şükûfe tabla

'Akkâm

fî 45

18

Kayık

fî 60

6

Fî 29 M sene 1154 (16 Nisan 1741)

Berây-1

Bâ-fermân-1 'âlî Şehzâdebaşı'ndaki konağına

Şehzâde bağçesine Sad-berg küpü tağâri ${ }^{74}$

37 , fî 80

Şebbû ${ }^{75}$ tağânı

Kapuda
bağçesine

Hercâi benefe ${ }^{76}$ tağârı $60+20$, fî̀ 18 Frenk bâtiyesi tağânı 40

100 , fi 6

Kayık ve hammâliyesi

480

Yekûn

4.400

\footnotetext{
${ }^{74}$ Tağâr (Dağâr): Kap, çanak, küp, çömlek. Türk Dil Kurumu, Tarama Sözlüğü, C.II, Ankara 1965, s.965.

${ }_{75}^{75}$ Şebbû : Şebboy çiçeği

${ }^{76}$ Benefe $=$ Benefşe $=$ Menekşe.
} 


\section{Yekûn}

Dökme meyve sepet

708, fi 70

49.560

Meyve-i mütenevvi'a sepet

660, fi 45

29.700

Şükûfe tabla

142 , fi 480

68.160

Hammâliye

'Akkâma ihrâc edilen ve elçilere giden

484

fî 15

Yekûn

69

$\frac{415}{6225}$

$\frac{415}{6.225}$

Bâlâdaki mestûr olan 'akkâm

Elçi-i Acem ve Moskov ve Françe elçisine

Kayık

Yekûn

Bâlâdaki şükûfe dağan

Yekûn

\begin{tabular}{ll}
\hline 69, fî 45 & 3.105 \\
24 , fi 60 & $\frac{1.440}{4.545}$ \\
\hline & $\frac{4.400}{8.945}$
\end{tabular}

\section{Yekûn}

Akçe

Guruş
162.590

Zuhûrât $\quad 1.345,5$

Yevmiye virilen $\underline{720.5}$

2.075

$\underline{0.075}$

2.000

Yalnız ikibin guruşdur.

İzzetlü hazînedâr Ağa.

İşbu Mâh-1 Muharremde Enderûn-1 hümâyûna küll-i yevm virilen meyve ve şükûfe bahâsı yediyüzyirmibuçuk guruş ve halvet-i hümâyûna ve iki def'ada yine Enderûn-1 hümâyûna virilen umûm meyvesi ve sâir elçilere gönderilen meyve ve şükûfe bahâsı dahî binüçyüzellidörtbuçuk guruş ki 
cem'an ikibinyetmişbeş guruşa bâliğ olup yetmişbeş guruşu tenzîl olunmağla kusûr iktiza eden ikibin guruşu devletlü 'inâyetlü veliyyü'n-ni'am efendimiz hazretleri sah buyurduklarından sonra mevcûd hazîneden virüp defter-i mesârife kayd eyleyesiz fî Selh-i M sene 154 .

(Belgenin Arka Yüzünde)

Derûn-1 defterde olan işbu Muharrem aylığında devletlü 'inâyetlü veliyyü'n-ni'am kesîrü'l-kerem efendimizin taraf-1 devletlerinden alınan meyve ve şükûfe bahâsı ikibin guruş tamâm hazîne-i veliyyü'n-ni'amdan olmak üzere sa'âdetlü hazînedârı el-Hâc Mehmed Ağa yedinden kusûr olmağla işbu varaka memhûr olmuşdur.

Bende-i el-Hâc Mehmed. 


\section{EK : 2}

\section{Cevdet Sarây, no. 2354}

Mâh-ı Ramazân-1 şerîfin gurresinden devletlü 'inâyetlü veliyyü'n-ni'am kesîrü'l-kerem efendimiz hazretlerinin taraf-ı devletlerinden be-her yevm şevketlü 'azametlü hünkârımıza ve dâire-i harem-i hümâyûnlarına virilen elli bir sepet meyve ve haftada iki gün Cum'a ve Pazarertesi virilen üçer tabla şükûfe beyân olunur sene 1158 Eyyâm 30 (27 Eylül-26 Ekim 1745).

\begin{tabular}{|c|c|c|c|c|c|}
\hline Günler & $\begin{array}{l}\text { Meyve } \\
\text { (Sepet) }\end{array}$ & $\begin{array}{l}\text { Şükûfe } \\
\text { (Tabla) }\end{array}$ & Günler & $\begin{array}{l}\text { Meyve } \\
\text { (Sepet) }\end{array}$ & $\begin{array}{l}\text { Şükûfe } \\
\text { (Tabla) }\end{array}$ \\
\hline $1 \mathrm{~N}^{77}$ Yevm-i Pazarertesi & 51 & 3 & 16 N Yevm-i Salı & 51 & - \\
\hline 2 N Yevm-i Salı & 51 & - & 17 N Yevm-j Çıhârşenbe & 51 & - \\
\hline 3 N Yevm-i Çıhârşenbe & 51 & - & 18 N Yevm-i Pençşenbe & 51 & - \\
\hline 4 N Yevm-i Pençşenbe & 51 & - & 19 N Yevm-i Cum'a & 51 & 3 \\
\hline $5 \mathrm{~N}$ Yevm-i Cum'a & 51 & 3 & 20 N Yevm-i Cum'aertesi & 51 & - \\
\hline $6 \mathrm{~N}$ Yevm-i Cum'aertesi & 51 & - & 21 N Yevm-i Pazar & 51 & - \\
\hline 7 N Yevm-i Pazar & 51 & - & 22 N Yevm-i Pazarertesi & 51 & 3 \\
\hline 8 N Yevm-i Pazarertesi & 51 & 3 & 23 N Yevm-i Salı & 51 & - \\
\hline 9 N Yevm-i Salı & 51 & - & 24 N Yevm-i Çıhârşenbe & 51 & - \\
\hline 10 N Yevm-i Çı̆hârşenbe & 51 & - & 25 N Yevm-i Pençşenbe & 51 & - \\
\hline $11 \mathrm{~N}$ Yevm-i Pençşenbe & 51 & - & 26 N Yevm-i Cum'a & 51 & 3 \\
\hline 12 N Yevm-i Cum'a & 51 & 3 & 27 N Yevm-i Cum'aertesi & 51 & - \\
\hline 13 N Yevm-i Cum'aertesi & 51 & - & 28 N Yevm-i Pazar & 51 & - \\
\hline 14 N Yevm-i Pazar & 51 & - & 29 N Yevm-i Pazarertesi & 51 & 3 \\
\hline 15 N Yevm-i Pazarertesi & 51 & 3 & $30 \mathrm{~N}$ Yevm-i Salı & 51 & - \\
\hline
\end{tabular}

Yekûn Eyyâm

$\begin{array}{lll}\text { Meyve sepet } & 1.530, \text { fî } 45 & 68.850 \\ \text { Şükûfe tabla } & 27, \text { fĩ } 480 & 12.960 \\ \text { Hammâliye } & 409, \text { fî } 15 & 6.135\end{array}$

Yekûn

Guruş

${ }^{\pi} \mathrm{N}$ : Ramazân 
Berây-1 ez-zuhûrât şehr-i minhu

Fî 5 N sene 158 (1 Ekim 1745)

Berây-1

Bâ-fermân-1 'âlişân veya emr-i devletlü kethüdâ beg

Şevketlü efendimiz Ağa Câmi'ine vardıkları gün telhîsci ağa ma'rifetiyle sarây-1 hümâyûna gönderilen

$\begin{array}{lll} & \text { Mübârek Rikâb-1 Hümâyûna } & 80 \\ \text { Hazret-i Ağa-yı Dârü's-sa'âdeye } & 50 \\ \text { Hôkme meyve sepet } & \text { Yekûn } & 20 \\ & & 150 \\ & \text { Mübârek Rikâb-i Hümâyûna } & \\ \text { Şükûfe tabla } & \text { Hazret-i Ağa-yı Dârü's-sa‘âdeye } & 8 \\ & \text { Hâzin-i Hazret-i Şehriyârîye } & 5 \\ & \text { Yekûn } & 2 \\ & & 15\end{array}$

\section{Fî $12 \mathrm{~N}$ sene 158 (8 Ekim 1745)}

Berây-1

Bâ-fermân-1 'âlişân devletlü 'inâyetlü veliyyü'n-ni'am efendimiz veya emr-i 'âlî-i devletlü 'inâyetlü kethüdâ beg efendimiz göç-i hümâyûn Topkapusundan sarây-1 hümâyûna geldiklerinde telhîsci ağa yediyle

\begin{tabular}{|c|c|c|c|}
\hline & $\begin{array}{l}\text { Şükûfe } \\
\text { (Tabla) }\end{array}$ & $\begin{array}{l}\text { Meyve } \\
\text { (Sepet) }\end{array}$ & $\begin{array}{l}\text { Dökme } \\
\text { Meyve } \\
\text { (Sepet) }\end{array}$ \\
\hline Mübârek Rikâb-1 Hümâyûna & 8 & -- & 80 \\
\hline Hazret-i Ağa-yı Dârü’s-sa‘âde el-aliyye & 5 & -- & 50 \\
\hline İsmetlü Baş Kadın Hazretlerine & 3 & -- & 30 \\
\hline İsmetlü İkinci Kadın Hazretlerine & 2 & 25 & -- \\
\hline Yekûn & 18 & 25 & 160 \\
\hline İsmetlü Üçüncü Kadın Hazretlerine & 2 & 25 & - \\
\hline İsmetlü Dördüncủ Kadın Hazretlerine & 2 & 25 & -- \\
\hline İsmetlï Beşinci Kadın Hazretlerine & 2 & 25 & --- \\
\hline İsmetlü Kethüdâ Kadın Hazretlerine & 2 & 25 & $\cdots$ \\
\hline İsmetlü Hazînedâr Ustaya & 2 & 25 & -- \\
\hline Yekûn & 28 & 150 & 160 \\
\hline Sa‘âdetlü Hazînedâr-1 Şehriyârî & 2 & -- & 20 \\
\hline
\end{tabular}


Oda Lalasina 110

Başkapu Gulâmına

1

Yazıcı Efendi'ye

Baltacılar Kethuidâsına

1

$1 \quad 10$

Ser-Kahve-i Ağa-i Dârü's-sa‘âde el-aliyye

110

Ser-Kahve-i Hazînedâr-1 Şehriyârî

1

Vekîl-i harc-1 Teberdârân

1

37

180

\section{Fî $30 \mathrm{~N}$ sene 158 (26 Ekim 1745)}

Berây-1

Bâ-fermân-1 'âlî Arîfe günü sultân-1 'âlîşân hazerâtına

\begin{tabular}{|c|c|c|}
\hline & $\begin{array}{l}\text { Şukûfe } \\
\text { (Tabla) }\end{array}$ & $\begin{array}{l}\text { Dökme } \\
\text { Meyve } \\
\text { (Sepet) }\end{array}$ \\
\hline Ismetlü ‘Âyşe Sultân Hazretlerine & 4 & 48 \\
\hline Ismetlü Safiye Sultân Hazretlerine & 4 & 48 \\
\hline Ismetlü Zeyneb Sultân Hazretlerine & 4 & 48 \\
\hline Yekûn & 12 & 144 \\
\hline İsmetlü Küçük ‘ Âyşe Sultân Hazretlerine & 4 & 48 \\
\hline İsmetlü Sâliha Sultân Hazretlerine & 4 & 48 \\
\hline İsmetlü Esmâ Sultân Hazretlerine & 4 & 48 \\
\hline Yekûn & 24 & 288 \\
\hline ‘An cânib-i Ağa-yı Yeniçeriyân & 8 & 80 \\
\hline Yekûn & 16 & 208 \\
\hline ‘An cânib-i Emîn-i Gümrük İshâk Ağa & 8 & 80 \\
\hline Yekûn & 8 & 128 \\
\hline
\end{tabular}




\section{Fî $30 \mathrm{~N}$ sene 158 (26 Ekim 1745)}

Berây-1

Arîfe günü fazîletlü Şeyhü'l-islâm efendi hazretlerine kapucular kethüdâsı ağa ma'rifetiyle

$\begin{array}{ll}\text { Dökme meyve sepet } & 40\end{array}$

Şükûfe tabla

Yekûn

$\begin{array}{lll}\text { Dökme meyve sepet } & 498, \text { fi } 70 & 34.860 \\ \text { Meyve sepet } & 220, \text { fî } 45 & 9.900 \\ \text { Şükûfe tabla } & 65, \text { fi } 480 & 31.200 \\ \text { Hammâliye } & 245, \text { fî } 30 & 7.350\end{array}$

\section{Yekûn}

Akçe

Guruş

Tenzîl

İzzetlü hazînedâr Ağa

İşbu defter mûcibince yalnız bindörtyüzyirmi guruşu yemişcibaşıya viresiz fî Selh-i N sene 158 (26 Ekim 1745).

Vech-i meşrûha üzere mezbûr defterde zikr olunan bindörtyüzyirmi guruş mâh-1 Ramazân-1 şerîf aylığı olmak üzere târîh-i mezbûrda sa'âdetlü hazînedâr ağa yedinden temâmen ahz ve kabz olmağla işbu mahalle şerh verildi fî $18 \mathrm{ZA}$ sene 158 (12 Aralık 1745).

Bende-i Yemişciyân Çelebi Ağa. 
Muharrem 1154 tarihli listenin baş tarafı

(Cevdet Saray, no. 2608)

院

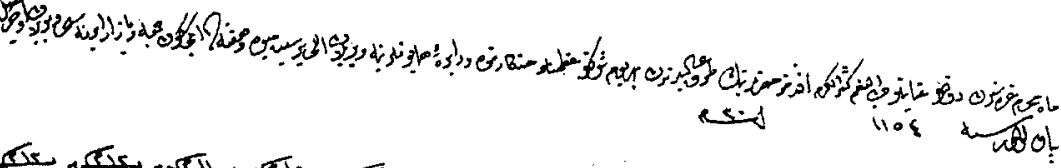

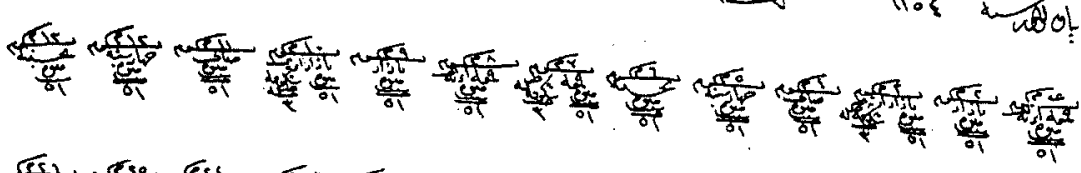

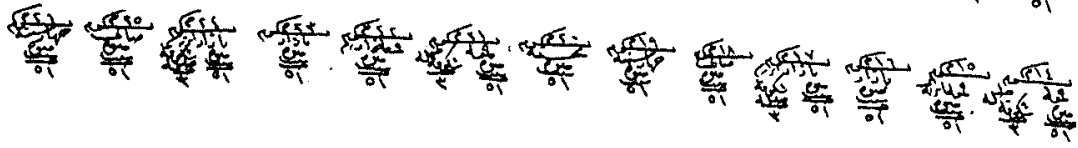
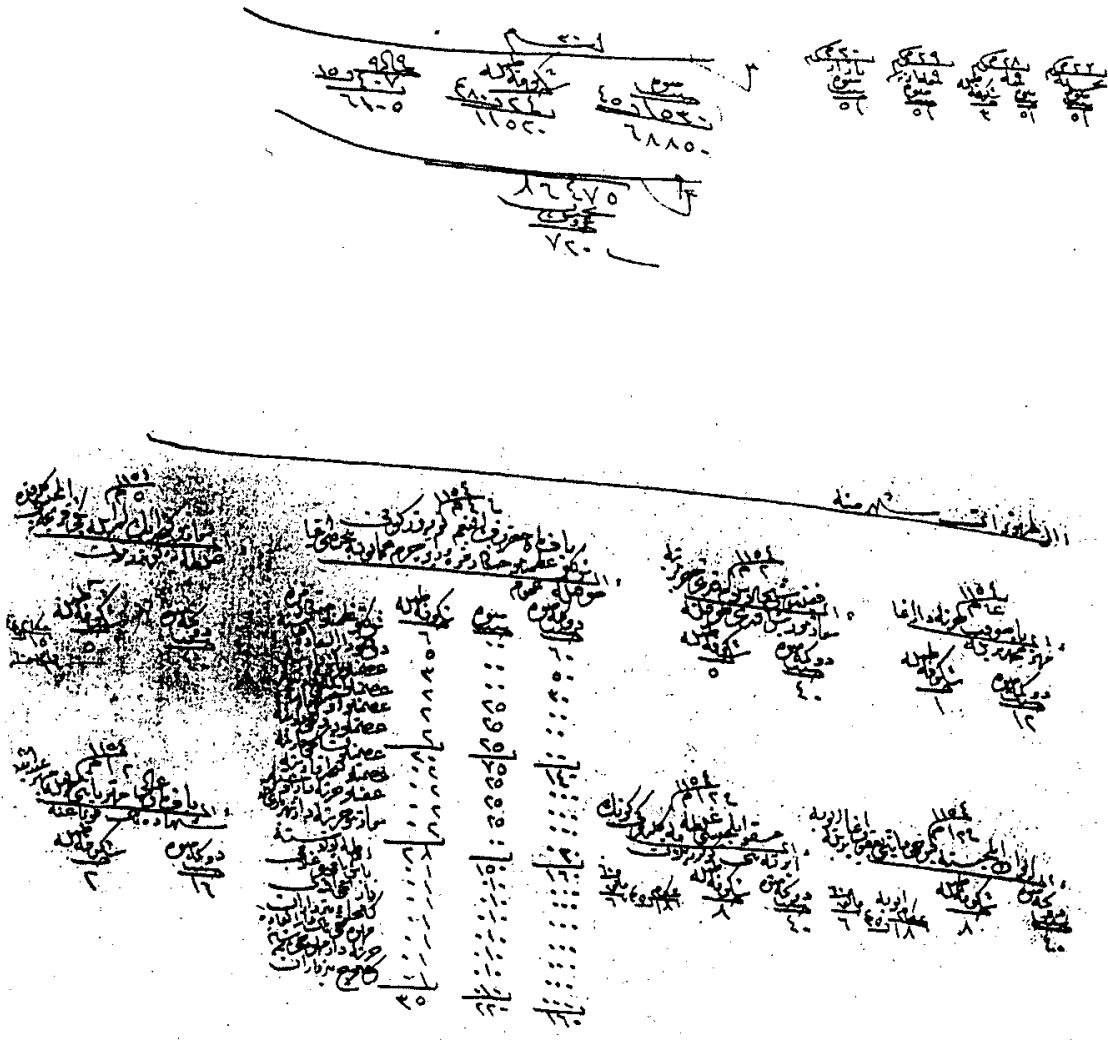